Review

\title{
Sensing the Deadliest Toxin: Technologies for Botulinum Neurotoxin Detection
}

\section{Petr Čapek ${ }^{1}$ and Tobin J. Dickerson ${ }^{2, *}$}

1 Department of Chemistry, The Scripps Research Institute, 10550 North Torrey Pines Road, La Jolla, CA 92037, USA; E-Mail: capek@scripps.edu

2 Department of Chemistry and Worm Institute for Research and Medicine, The Scripps Research Institute, 10550 North Torrey Pines Road, La Jolla, CA 92037, USA

* Author to whom correspondence should be addressed; E-Mail: tobin@scripps.edu; Tel.: +1-858-784-2522; Fax: +1-858-784-2590.

Received: 1 December 2009; in revised form: 17 December 2009 / Accepted: 22 December 2009 / Published: 7 January 2010

\begin{abstract}
Sensitive and rapid detection of botulinum neurotoxins (BoNTs), the most poisonous substances known to date, is essential for studies of medical applications of BoNTs and detection of poisoned food, as well as for response to potential bioterrorist threats. Currently, the most common method of BoNT detection is the mouse bioassay. While this assay is sensitive, it is slow, quite expensive, has limited throughput and requires sacrificing animals. Herein, we discuss and compare recently developed alternative in vitro detection methods and assess their ability to supplement or replace the mouse bioassay in the analysis of complex matrix samples.
\end{abstract}

Keywords: botulinum neurotoxin; detection; endopeptidase; botulism; mouse lethality assay; ELISA; lateral flow test; mass spectrometry; FRET; immuno-PCR

\section{Introduction}

Botulinum neurotoxins (BoNTs) are the most poisonous substances known to humans, with a median lethal dose $\left(\mathrm{LD}_{50}\right)$ of approximately $1 \mathrm{ng}$ per $\mathrm{kg}$ of body weight [1] and are the cause of the life-threatening neuroparalytic disease botulism [2]. BoNT intoxication is presented by flaccid paralysis originating from an inhibition of neuromuscular signal transmission. Lethality of the disease 
is then connected with muscle paralysis-caused respiratory failure. On a molecular level, BoNTs are zinc-dependent metalloproteases that cleave SNARE (soluble $N$-ethylmaleimide-sensitive factor attachment protein receptor) complex proteins that are critical for the release of the neurotransmitter acetylcholine from neuronal cells [3].

BoNTs are produced by the Gram-positive anaerobic soil bacterium Clostridium botulinum [4], first discovered as a contaminant of poorly preserved ham in the late $19^{\text {th }}$ century. Besides soil and spoiled food, C. botulinum can grow in wounds or the human intestine and can be also cultured in large scale in a laboratory. Due to the extreme potency, lethality and easy procurement, BoNTs have the potential to be very dangerous biological weapon and therefore represent significant warfare and terrorism threat [5]. Consequently, BoNTs are one of the six category A agents listed as the highest risk threat agents for bioterrorism by the US Centers for Disease Control and Prevention (CDC) [6].

Apart from being a dangerous biohazard agent causing incidental death and a potential biological weapon, BoNTs also have important therapeutic value. These toxins are utilized in the treatment of a wide variety of conditions including cervical dystonia, strabismus, blepharospasms, hemifacial spasms, hyperhidrosis, myofacial pain, migraine headaches, vocal cord dysfunction, diabetic neuropathy, anal fissure and multiple sclerosis [7-9]. Additionally, the most well-known application of botulinum neurotoxin serotype A (BoNT/A) is its use in the cosmetic industry as an anti-wrinkle agent, under the commercial name Botox ${ }^{\circledR}$.

\subsection{Molecular Mechanism of BoNT Action}

BoNTs are produced by $C$. botulinum as a single $150 \mathrm{kDa}$ inactive protein, which becomes activated by proteolytic cleavage into the light chain (LC) metalloprotease catalytic domain (50 kDa) and heavy chain (HC), which consists of translocation and binding domains (100 kDa) [10]. These two chains are linked as a heterodimer by a single disulfide bond, as well as numerous non-covalent interactions between the two peptide chains. There are seven different serotypes of BoNTs, named AG; these are up to $70 \%$ different at the amino acid sequence level, but all serotypes share similar folded conformations and identical activity at the organismal level, albeit with slightly different molecular targets.

BoNT intoxication occurs in three steps: (i) neuronal cell specific binding and internalization by receptor-mediated endocytosis, (ii) translocation and release of the LC into the cytosol and (iii) cleavage of the SNARE complex proteins (Figure 1) [11]. Examining this process in more detail, toxin binding to neuronal cells occurs via HC binding to two receptors. Toxin first associates with the cell membrane via a ganglioside followed by migration of the complex to its cognate protein receptor $[12,13]$. Upon binding to both receptors, toxin is then internalized by endocytosis. After endocytosis, LC escapes the endosome through an endosome membrane translocation process [11]. It is believed that as the $\mathrm{pH}$ in the endosome lowers, it triggers a subsequent conformation change in the toxin, resulting in the $\mathrm{HC}$ acting as a transport channel and chaperone, facilitating LC translocation through the endosome membrane and into the cytosol [14,15]. Finally, inside the cytosol, the LC acts as zinc-dependent metalloprotease and cleaves proteins of the SNARE complex, which are the part of exocytosis apparatus, effectively destroying this apparatus and leading to inhibition of neurotransmitter release [3]. In this last step of SNARE complex protein cleavage, each of the seven different BoNT 
serotypes cleaves a unique peptide bond located on one of the SNARE proteins [16-18]. BoNT/A, /C and /E cleave synaptosomal associated protein of $25 \mathrm{kDa}$ (SNAP-25), at positions 197-198, 198-199 and 180-181, respectively. BoNT/B, /D, /F and /G target synaptobrevin, cleaving at positions 76-77, 59-60, 59-59 and 81-82, respectively. Interestingly, in addition to SNAP-25, BoNT/C also cleaves syntaxin at position 253-254.

Figure 1. Mechanism of action of botulinum neurotoxin. Left side: Release of acetylcholine at the neuromuscular junction is mediated by the assembly of the SNARE protein complex, allowing the the membrane of the synaptic vesicle containing acetylcholine to fuse with the neuronal cell membrane. SNARE protein complex includes synaptobrevin, SNAP-25, and syntaxin. Right Side: BoNT binds to the cell membrane and enters the neuron by endocytosis, the light chain is translocated through the membrane and then cleaves specific sites on the SNARE proteins, preventing complete assembly of the synaptic fusion complex and thereby blocking acetylcholine release. Botulinum toxins types B, D, F, and G cleave synaptobrevin; types A, C, and E cleave SNAP-25; and type C cleaves syntaxin. Reprinted with permission from [19]. Copyright (C) 2002 Massachusetts Medical Society. All rights reserved.
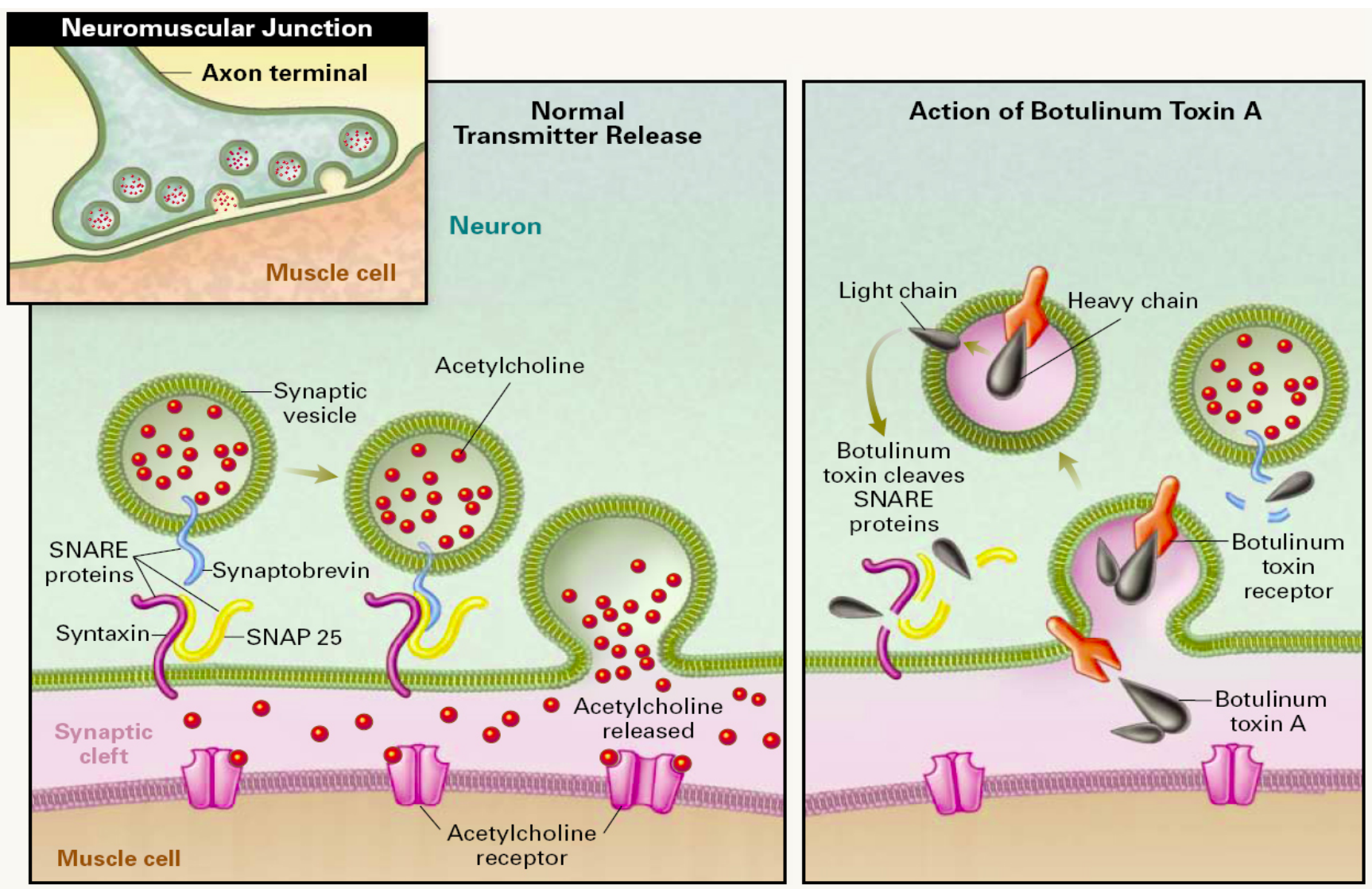

\subsection{Botulism}

Human botulism is caused mainly by BoNT/A, /B, /E and occasionally /F, with BoNT/A being the most poisonous to humans followed by BoNT/B. Ingestion of food contaminated with BoNTproducing C. botulinum, wound infections and intestinal colonizing infections in infants (as well as 
adults with misbalanced intestinal flora) are three most common causes of botulism disease [5,20,21]. In the case of an infected wound or intestine, toxin is produced in vivo by C. botulinum. The symptoms and manifestation of botulism are identical for all serotypes, with the onset of flaccid paralysis usually occurring within 12 to 48 hours after intoxication. Muscle paralysis typically starts with the facial muscles controlled by cranial nerves, causing double vision, drooping eyelids, etc. and continues to descend into shoulders, arms and finally legs. Severe botulism leads to paralysis of respiratory muscles and respiratory failure [22].

Treatment of botulism has to be started as soon as possible after intoxication as paralysis cannot be reversed by any therapeutic intervention. The current standard of care consists of administration of equine antitoxin (commonly antibodies against three serotypes, BoNT/A, /B and /E) which binds to toxin that has not yet internalized into neuronal cells. It is critical to note that antitoxin is unable to enter poisoned cells and reverse the paralysis. Other support such as mechanical ventilation is provided to patients with severe botulism for weeks or months until full recovery [22].

\section{BoNT Detection}

Due to the extreme toxicity, the speed of symptom onset and lack of treatment to reverse paralysis, a sensitive and rapid BoNT detection method is needed to diagnose botulism in suspected cases before paralysis occurs. Additionally, there is a great need for the sensitive detection of BoNT outside of clinical diagnostics. As mentioned above, BoNT represents a high bioterrorism threat. In the case of a terrorist attack, rapid, sensitive and field deployable detection would be needed to assess the extent of contamination and to take necessary action. Finally, with the ever-increasing medical use of BoNT, its sensitive and specific detection in manufacturing processes as well as clinical research laboratories is of crucial importance. Methods of BoNT detection were recently reviewed in several excellent publications [23-25]. This article is intended to give the reader an update on the most recent developments and put them into the context of previously reported methods.

\section{Mouse Lethality Assay}

Despite enormous progress in the development of alternative in vitro methods for botulinum neurotoxin detection [23-25], the mouse lethality assay has remained the only accepted standard test to confirm active BoNTs [26]. This test is based on intraperitoneal injection of mice with dilutions of BoNT-suspected samples and subsequent observation of these mice for symptoms of botulism and, ultimately, death. Such symptoms include fuzzy hair, muscle weakness, narrowed waist, gasping for breath, and subsequent respiratory failure that usually occurs during the first $48 \mathrm{~h}$ post injection. It is necessary to find both the maximum sample dilution that kills mice and the minimum dilution that does not kill in order to estimate the quantity of BoNT in the sample. If the dilution that does not kill is not found and all injected animals die, the sample has to be diluted further and the procedure repeated [26]. The quantity of toxin in the sample is then estimated by relating the maximum dilution which kills to the known mouse lethal dose (MLD $50,10 \mathrm{pg}$ for BoNT/A) [27]. The toxin serotype is then determined by neutralization of the toxin with serotype specific antitoxin usually administrated prior to toxin injection. Mice are observed for signs of botulism for another $48 \mathrm{~h}$ to conclude which 
specific antitoxin is protective. Thus, in order to appropriately conduct this assay, a minimum of four to six days are required before an estimate of toxin concentration can be obtained.

The mouse lethality assay has been used for analysis of complex sample matrices ranging from bacterial cultures to serum, fecal, gastric and wound samples. Examples of matrix interference with the assay are known, particularly when other substances or toxins present in the sample cause lethality $[28,29]$, but the assay is generally considered to be highly sensitive and specific. Another advantage is that it detects functionally active toxin, unlike the majority of immunological methods that do not provide information about toxin activity. However, this is not to imply that the mouse lethality assay is without substantial drawbacks. Several laboratory animals have to be sacrificed for one test, the procedure is laborious and expensive and inherently limited to laboratories with an animal facility. Furthermore, a single test with serotype determination takes a minimum of four days to perform. This is unacceptably long when fast action is needed, for example, in suspected clinical cases of botulism.

\subsection{Variations of Mouse Bioassay}

Variations of the mouse lethality assay have been developed to reduce the number of laboratory mice required. One variation relates the toxin quantity to the severity of local symptoms (e.g., paralysis), their offset and time-to-death after subcutaneous injection of the sample at the inguinocrural region [30]. This method can estimate BoNT/A quantities ranging from as little as 0.075 mouse $\mathrm{LD}_{50}$ to an upper detection limit of about $38 \mathrm{LD}_{50}$ s (sensitivity over nearly 3 logs) with just one animal. A similar method based on assessing the severity of flaccid paralysis was developed to analyze low concentrations of therapeutic samples of BoNT/A without the necessity of a terminal end point [31]. In another related method, toxin dilution is injected intravenously and time-to-death is correlated to toxin concentration [32].

More recently, a rat test was developed in which a direct measure of neuromuscular signal transmission, the compound muscle action potential (CMAP), was used to quantify BoNT concentration [33]. The CMAP is generated by the contraction of muscle fiber and changes in the resulting micro current can be directly measured upon toxin treatment. One day post treatment, BoNT/A, C and E could be detected at levels lower than 1 MLD $_{50}$ (with BoNT/A having significant effect on CMAP at levels as low as $0.03 \mathrm{MLD}_{50}$ ). The related in vitro mouse/rat hemidiaphragm muscle contraction assay correlates muscle twitch tensions to the toxin concentration [34]. In this in vitro method, hemidiaphragm preparations with attached phrenic nerves are stimulated with a supramaximal pulse and the resulting tension of muscle twitches is recorded. The signal from preparations treated with BoNT is compared to the pre-treatment signal to estimate the toxin concentration. The assay was successfully utilized in a development of BoNT antagonists [35,36].

All of these methods can estimate toxin quantity with significantly fewer animals required than the mouse lethality assay, but the toxin serotype must be known in advance to correlate symptoms and survival times to dose. If the serotype is unknown, a toxin neutralization assay or alternative assay has to be performed to determine which serotype is present. However, all of these mice/rat based assays still have limitations inherently connected to animal experiments, including necessity of an animal 
facility. In addition, the assays are slow when immediate action is needed, have very limited throughput and are impossible to automate.

\section{In Vitro Methods of BoNT Detection}

Alternative in vitro methods for detection of BoNT have been developed to overcome some of the limitations of the mouse bioassay [23-25,37]. The majority of the in vitro assays developed over the last four decades are immunological methods based on the binding of an antibody to the toxin. As such, they are usually easier to perform and are significantly faster; however, unlike mouse bioassays, immunological assays do not discriminate between functionally active and inactive form of the toxin. Early implementation of immunological methods relied on technologies such as radioimmunoassays [38,39], passive hemagglutination assays [40], and immunodiffusion assays [41-44]. Ultimately, these assays were overcome by more sensitive Enzyme-Linked Immunosorbent Assays (ELISA).

\section{ELISA}

Over three decades of use for BoNT detection [45-47], ELISA has become by far the most commonly employed method for in vitro detection of the toxin [23-25]. As a means of detection, ELISA uses specific antibody binding to the toxin. In a typical sandwich ELISA setup, wells of a microtiter plate are first coated with a capture antibody that is specific for the toxin, followed by nonspecific blocking of the remaining well surface by an unrelated protein (e.g., bovine serum albumin, BSA). Then, sample putatively containing the toxin is applied to the well and if present, the toxin binds to the capture antibody, while other components of the sample and matrix are washed out. Subsequently, a detection antibody conjugated to a suitable reporter (e.g., horseradish peroxidase (HRP), alkaline phosphatase) binds specifically to the immobilized toxin. The reporter enzyme then converts a colorless chromogenic substrate (e.g., 3,3',5,5'-tetramethylbenzidine, TMB, in case of HRP) into a colored product which is spectroscopically quantified using a plate reader. Signal is then compared to a standard calibration curve and the toxin quantity is interpolated. The experiment usually takes 5-6 hours to complete, and is significantly faster than mouse lethality assay. ELISAs with an experimental setup analogous to this were reported to have a wide range of sensitivities, depending on the specific antibody and reporter system used, and have been employed for detection of all BoNT serotypes [48-51].

Several variations of the ELISA protocol were developed to enhance assay sensitivity. In an amplified ELISA, alkaline phosphatase linked to secondary antibody converts reduced nicotinamide adenine dinucleotide phosphate (NADPH) to reduced nicotinamide adenine dinucleotide (NADH). The resulting NADH then triggers a secondary cyclic enzymatic reaction, that is, the reduction of iodonitrotetrazolium violet (INT-violet) to an intensely colored formazane dye, which can be spectroscopically detected. Amplified ELISA was used for detection of BoNTs with sensitivities ranging from 1-10 $\mathrm{MLD}_{50}[27,52,53]$. This technique has been accepted as a method for prescreening the toxin samples prior to the mouse lethality assay [26], and validated for screening of food samples [54]. Another example of an amplification system used to enhance the sensitivity of ELISA is the Enzyme-Linked Coagulation Assay (ELCA) [55-57]. ELISA-ELCA relies on a complex multistep 
amplification cascade starting with cleavage of factor $\mathrm{X}$ by snake venom coagulation factor conjugated to a detection antibody and ending with the color change of an alkaline phosphatase substrate. Despite the good sensitivity of this method, which is comparable to or exceeding that of mouse lethality assay ( $<1 \mathrm{MLD}_{50}$ ), it has not been widely accepted due to its excessive complexity.

Serotype specificity of the ELISA depends on the specificity and cross-reactivity of the antibodies used. All BoNT serotypes are immunogenic and can elicit production of antitoxin antibodies. The seven serotypes differ by up to $70 \%$ on the amino acid level, thus making the selection of antibodies with little or no cross-reactivity possible [58]. Both monoclonal and polyclonal antibodies have been used in ELISA experiments for the detection and serotyping of BoNTs, with polyclonals being more common due to reduced procurement costs and easier accessibility. Polyclonal antibodies with high specificity against serotypes A, B, E, and F (serotypes generally causing human disease) were employed to identify these BoNT serotypes by amplified-ELISA (amp-ELISA) and ELISA with digoxigenin-labeled antibodies (DIG-ELISA) [26,27] with high sensitivity in the range of 1-10 MLD 50 and no cross-reactivity. Like amp-ELISA, DIG-ELISA was developed by the Food and Drug Administration (FDA) for prescreening samples for the presence of BoNTs prior to the mouse lethality assay [26]. Sensitive ELISAs relying on monoclonal antibodies with high serotype specificity have also been developed [48].

ELISA methodologies have been successfully employed in the detection and quantification of purified botulinum toxin [49,51,59], in C. botulinum cultures that produce the toxin [60-62], in an extensive variety of food samples [52,54,63-65] (both contaminated food and food artificially spiked with the toxin), and in clinical samples such as serum [49] and feces [66]. Some foods tend to interfere with ELISAs and decrease their sensitivity; therefore, results should be confirmed by mouse lethality assay. The degree of food sample interference with ELISAs is difficult to anticipate de novo and must be examined on an individual basis. However, there are some general considerations to make; for example, protocols employing biotinylated reagents (e.g., antibodies) are not suitable for investigation of samples containing eggs due to the high content of avidin in egg whites. Furthermore, interference of clinical samples of feces with ELISAs may be even more severe than that of food samples [66]. It has been shown that conditions of the assay can be modified appropriately (e.g., with dilution into fetal bovine serum (FBS) buffer) to decrease the amount of the feces sample interference [66].

\subsection{Alternative ELISA Formats}

Apart from antibody capture, peptide capture-based ELISAs have also been developed as a sensitive and cheaper alternative as large quantities of peptide can be chemically synthesized, contrary to the significant expense of antibody production [67]. An 11-mer cyclic peptide identified by phage display technology was attached to a polymer matrix and used as capture phase in an ELISA experiment (Figure 2). In this case, the capture peptide polymer showed high specificity for BoNT/A, bringing sensitivity of the assay to a respectable $1 \mathrm{pg} / \mathrm{ml}$ of BoNT/A [67].

Another variation introduced into ELISA protocols is the use of ganglioside-bearing liposomes as the detection agent, substituting the detection antibody [68]. Gangliosides are glycosphingolipids present in the membranes of neuronal and other cells known to be receptors for bacterial toxins [69,70], with the trisialoganglioside GT1b characterized as a co-receptor of BoNTs [71,72]. 
Gangliosides were embedded into the membrane of liposomes together with fluorophore-labeled lipid, and bound to the capture antibody/toxin complex as the detection agent. High theoretical amplification of signal can be achieved due to the fact that every liposome carries tens of thousands of fluorophore molecules. However, the sensitivity of the method for BoNT/A was only $150 \mathrm{ng} / \mathrm{ml}$, presumably owing to unspecific interactions of the liposomes.

Figure 2. Cyclic peptide identified by phage display conjugated to the polymer used as the capture agent in an ELISA. Reprinted from [67], Copyright (C) 2006, with permission from Elsevier.

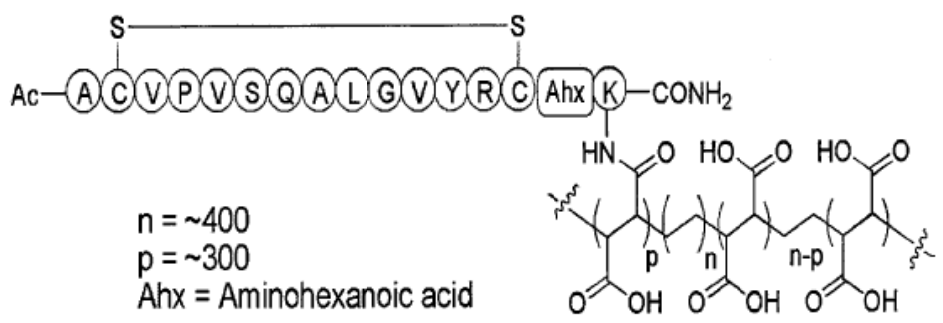

Systems for automated ELISAs relying on plate washers and liquid handlers are available to accelerate BoNT detection experiments and reduce the labor requirements. Alternatively, an automated fluidic system consisting of a pump, multichannel selection valve, renewable surface flow cell and on cell detector has been developed to perform sandwich immunoassays (Figure 3) [73-76]. A given sample solution is applied on beads coated with capture antibody, followed by application of detection antibody and readout by built-in detector, all in an autonomous fashion. Rapid detection (20 min) of BoNT/A heavy chain fragment was achieved with sensitivity around $1 \mathrm{ng} / \mathrm{mL}$ [73,74]. While this sensitivity does not compare favorably with ELISA assays, the development of automated and fast detection methodologies remains a topic of interest in the detection of BoNTs.

Figure 3. Diagram of the fluidic system with renewable surface flow cell (in detail on the right) used for autonomous BoNT detection. Reprinted from [73], Copyright (c) 2009, with permission from Elsevier.
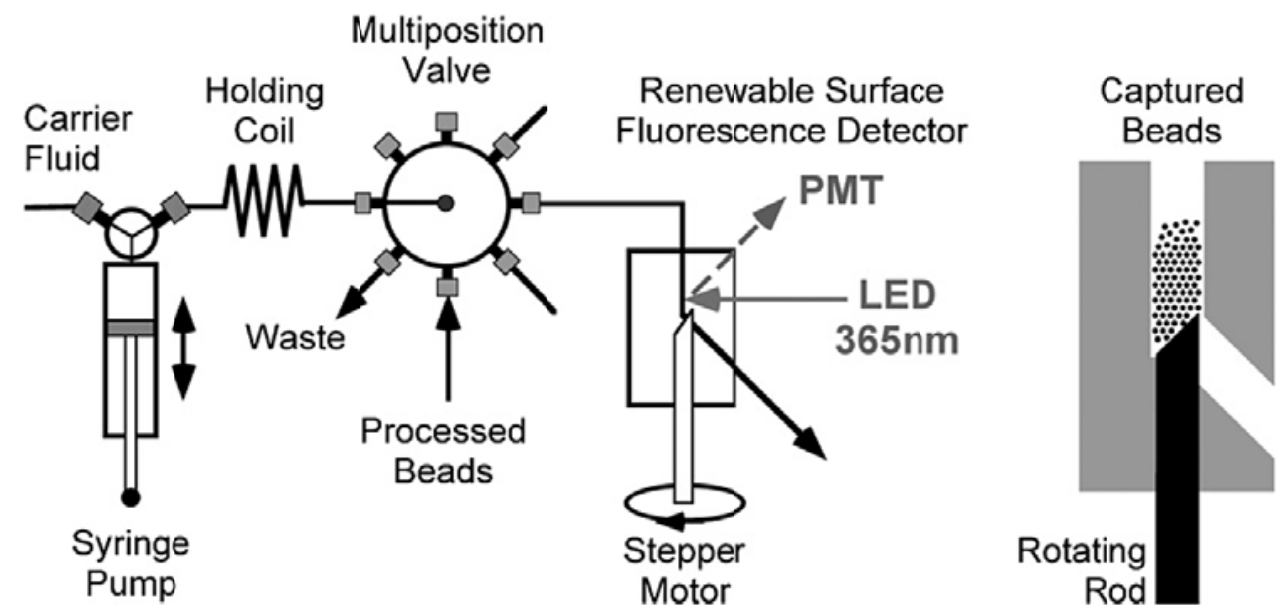


\section{Flow Cytometric Assays}

Fluorescent sandwich immunoassays have been also performed on beads with flow cytometry instrumentation used to detect and quantify toxin [77-79]. Detection of BoNT/A and BoNT/B was performed in multiplex with other toxins (e.g., cholera toxin, ricin and staphylococcal enterotoxin B (SEB)) using different color-coded beads [78,79]. The use of magnetic beads in flow cytometry was shown to have several advantages including that a preconcentration step can be involved, resulting in increased sensitivity and making analysis of turbid or heterogenous samples possible as beads can be easily separated from the matrix [79]. BoNT/A and B were detected at concentrations of $21 \mathrm{ng} / \mathrm{mL}$ and $73 \mathrm{ng} / \mathrm{mL}$, respectively, in 5-plex assay together with ricin, SEB and abrin. This sensitivity was comparable to the sensitivity of an ELISA performed for one analyte at the time with the same set of antibodies (detection limits of $12 \mathrm{ng} / \mathrm{mL}$ and $124 \mathrm{ng} / \mathrm{mL}$, respectively, for BoNT/A and B). Another assay was performed using an automatic fluidic system format. Beads with capture antibody were trapped in a flow cell, where sample toxin capture, washes, and binding of detection antibody were performed under the control of a system before flow cytometric analysis. The detection limit of this assay was found to be $50 \mathrm{pg} / \mathrm{ml}$ of BoNT/A heavy chain (used as nontoxic simulant) [77].

Although being based on the same principle of sandwich immunoassay, flow cytometric assays have several significant benefits over ELISA. Flow cytometric assays are easier to automate and therefore can be less laborious; assays are easier to multiplex and therefore, it is easier to interrogate samples for the presence of multiple toxins and/or several BoNT serotypes in one test tube; there are inherent advantages of capture on beads compared to a well surface including better capture kinetics and enhanced analyte concentration. Additionally, quantitation of toxin in a given sample by flow cytometric assay is faster than ELISA. Also, it is reasonable to expect that the sensitivity of flow cytometric assays will at least reach that of sensitive ELISAs. However, that does not imply that this technique is not without drawbacks. In particular, the instrumentation needed to perform flow cytometric analysis is significantly more expensive and complex than the plate-readers needed for ELISA.

\section{Electrochemiluminescence Immunoassay}

Electrochemiluminiscence (ECL) immunoassays have been employed in BoNT detection as an alternative to standard ELISAs [80-83]. In essence, ECL immunoassays rely on the same type of interactions between capture antibody, analyte and reporter antibody involved in the majority of immunoassays. The primary difference is that the reporter antibody in an ECL assay has an electrochemiluminiscence tag, such as a ruthenium (II) tris(bipyridyl) complex, which becomes luminescent in the presence of an electric potential. Unlike ELISA, ECL assays are typically performed on magnetic beads coated with capture antibody. Upon binding of the toxin and reporter antibody, beads are directed by a magnet to an electrode where the ECL reaction occurs. Potential gains in sensitivity can come from several sources: (i) higher luminescent signal-to-noise ratio; (ii) high surface area of beads allowing for denser antibody packing; (iii) enhanced kinetics of antibodyantigen interactions because beads are free in suspension; (iv) volume of sample probed by beads can 
be greater than the volume of the ECL detection reaction upon concentration of the beads by a magnet, introducing another amplification step.

In an early example of an ECL assay, BoNT/A was detected at concentrations as low as 5 $\mathrm{pg} / \mathrm{mL}$ [80]. Direct comparison of detection sensitivity of ECL and ELISA using the same antibodies and purified BoNT/B as analyte has been also performed [81]. With a detection limit of about $1 \mathrm{ng} / \mathrm{mL}$, the ECL methodology performed about four-fold better than comparable ELISA in terms of sensitivity and was twice as fast. In another assay, ECL was used for detection of BoNT/A, B, E and F in a limited number of foods and clinical samples [82]. Sensitivity in tested matrices ranged from $50 \mathrm{pg} / \mathrm{ml}$ (BoNT/A) to $400 \mathrm{pg} / \mathrm{mL}$. However, despite the above mentioned advantages of ECL, the sensitivity boost compared to ELISA is relatively marginal. Additionally, the number of matrices tested with ECL is very limited compared to ELISAs, and the equipment needed for ECL detection is more specific. Consequently, all of these issues preclude wide spread application of this method.

\section{Immuno-PCR}

The polymerase chain reaction (PCR) enables exponential amplification of a DNA template, making it a powerful tool for sensitive nucleic acid detection. Immuno-PCR is an ELISA-type immunoassay that uses PCR for exponential amplification of ELISA signal [84]. As in the classical sandwich ELISA described above, analyte (BoNT) is captured by the adsorbed antibody and detected by reporter antibody binding to preformed capture antibody/analyte complex. In the case of immunoPCR, the reporter antibody is a DNA-antibody conjugate with DNA used as an amplifiable tag. Amplification of DNA is performed either by normal PCR, which requires agarose gel electrophoresis detection of the PCR product, or more conveniently, by real-time quantitative PCR, which is capable of direct DNA quantification using fluorescent dye labeling of the formed PCR product.

Immuno-PCR has been used for detection of BoNT/A with sensitivity reaching that of the mouse lethality assay [85]. In another report, sensitivity of as little as $1 \mathrm{pg} / \mathrm{mL}$ of BoNT/A in buffer was accomplished, using streptavidin to connect the biotinylated DNA tag to biotinylated antibody instead of covalent DNA-antibody conjugation [86].

An alternative assay termed liposome-PCR has been developed recently to detect BoNT and cholera toxin $[87,88]$. In this assay, approximately 60 copies of reporter DNA are encapsulated in a liposome, which has its outside surface labeled with ganglioside (trisialoganglioside GT1b for BoNT binding, Figure 4). The surface GT1b of DNA-loaded liposomes then binds to a capture antibody/BoNT complex followed by liposome rupture and real-time quantitative PCR of released DNA. To eliminate contaminating DNA which could be present in the sample and could increase background signal, captured liposomes can be treated with DNase to digest any contaminating DNA outside of the liposomes. By liposome-PCR, BoNT/A at a concentration as low as $0.02 \mathrm{fg} / \mathrm{mL}$ was detected in purified water [87], making this method five orders of magnitude more sensitive than the mouse lethality assay and the most sensitive in vitro immunological method reported. However, application of this assay in the detection of BoNT in complex matrices was not reported. Nonspecific binding of liposomes, as well as their stability in presence of complex matrices, may be problematic and could be a significant drawback to this method. 
Figure 4. A representation of liposome-PCR reagents. The dsDNA reporter (green with red bars) is encapsulated inside the liposome (yellow) with ganglioside receptor (blue) incorporated into the membrane. Liposome reagent binds to the analyte (shown here as a pentameric protein) which is captured by an antibody. Reprinted by permission from Macmillan Publishers Ltd. from [87]. Copyright (c) 2006.

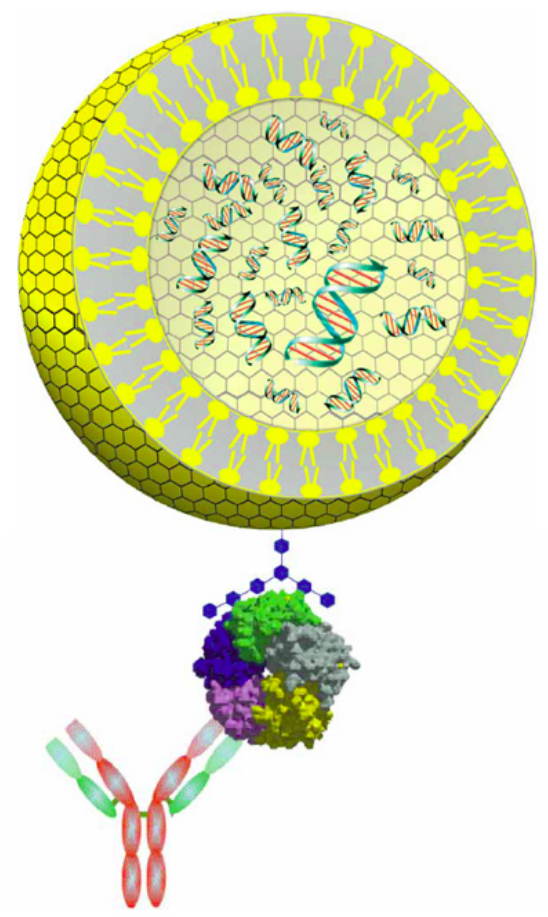

\section{Lateral Flow Tests}

The lateral flow test is a hand-held immunochromatographic assay that also relies on a capture antibody-analyte-detection antibody interaction, typically on a nitrocellulose strip resulting in visual (color) change of the strip. A good example of this type of detection device is the commercial pregnancy test. In the lateral flow test for BoNT detection, liquid toxin sample is applied on one end of the strip and then migrates towards the opposite end via capillary action. First, toxin binds to a detection agent (antibody) conjugated to reporter (e.g., dye, gold nanoparticles) then the whole complex toxin/detection antibody continues to migrate down to the strip, ultimately to be captured in the detection zone by the capture antibody, resulting in a color change in the detection zone (Figure 5).

Lateral flow tests have significant advantages over other detection methods. They are inexpensive, easy to use, generate a visual read-out with no equipment needed and are very rapid with a typical analysis taking only $15 \mathrm{~min}$. All of these properties make them ideal for field use by untrained personnel. However, the price for this ease of use is lower sensitivity compared to ELISA and other modern immunological methods. Typical limits of detection of lateral flow tests for BoNT employing detection antibody conjugated to gold nanoparticles range from 5 to $50 \mathrm{ng} / \mathrm{mL}$ (500-5,000 $\mathrm{MLD}_{50} / \mathrm{mL}$ ) [89-92]. Despite this reduced sensitivity, some of these assays are commercially available $[89,91]$. Successful detection of BoNT/A, B and E with lateral flow assay in a wide variety of food samples has been demonstrated, showing the importance of sample preparation and pre-treatment to increase assay reliability [89]. 
Figure 5. Schematic view of a typical lateral flow device on the left. Three possible results; positive, negative and inconclusive due to missing control signal, are shown on the right.

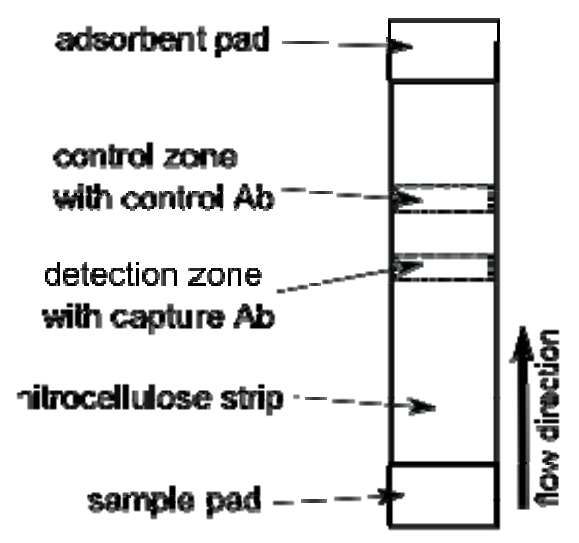

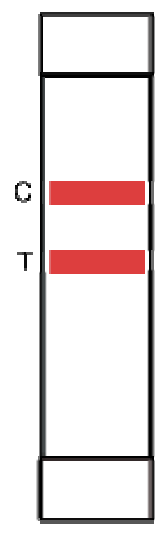

Positive
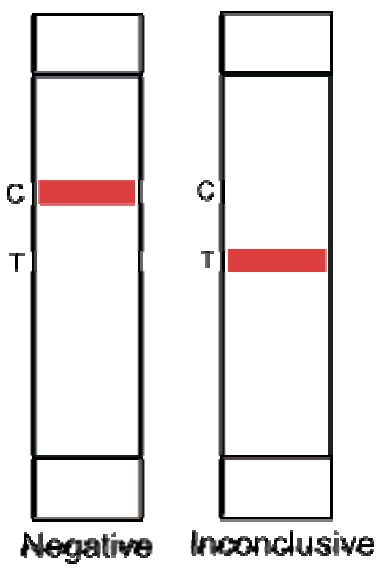

A system using a cross-flow immunochromatographic method was developed to enhance the sensitivity of the lateral flow BoNT assay [93]. This assay relies upon a detection antibody conjugated to HRP, instead of the more common gold nanoparticles or colloidal gold reporters. After application of the sample and development in one direction (vertical direction flow) as with a regular lateral flow assay, a HRP substrate is applied to the side and the strip is developed in the direction perpendicular to the first one (horizontal direction flow). The HRP chromogenic substrate migrates over the HRP enzyme in the capture zone and its cleavage translates into a color change, signaling presence of the toxin. The sensitivity of this assay is $2 \mathrm{ng} / \mathrm{mL}$ (200 $\left.\mathrm{MLD}_{50} / \mathrm{ml}\right)$ of BoNT/A [93]; a modest enhancement compared to gold nanoparticle-based devices is paid for by increased complexity of the device and the assay protocol. A more effective and simpler signal enhancement procedure using silver enhancer has been developed [94]. In this application, upon development, a lateral flow device employing colloidal gold conjugated reporter antibody was soaked in silver enhancer for $5 \mathrm{~min}$ followed by fixing for $3 \mathrm{~min}$. This procedure increased sensitivity of the method 1,000-fold from $50 \mathrm{ng} / \mathrm{mL}$ of BoNT/B to $50 \mathrm{pg} / \mathrm{mL}$.

A lateral flow assay with significantly improved sensitivity has also been reported that uses ganglioside-liposomes as the detection agent [95]. Trisialoganglioside GT1b was incorporated by means of its fatty tails into liposomes containing sulforhodamine B dye as a visualization agent to form stable ganglioside-liposomes. These liposomes were used as the detection agent in a lateral flow device and upon binding to the BoNT/A, migrated to reach the detection zone. There, the toxin/gangliosideliposome complex was retained by the capture antibody, forming a macroscopically visible band. The detection limit of this device was reported to be an impressive $15 \mathrm{pg} / \mathrm{mL}\left(1.5 \mathrm{MLD} \mathrm{D}_{50} / \mathrm{mL}\right)$ of BoNT/A in buffer [95]. However, successful application of this method to the detection of the toxin in complex matrices has not been demonstrated.

\section{Biosensors}

Fluorescence-based biosensors are an emerging type of automated portable devices for rapid detection of BoNTs and other biohazard materials [96,97]. Typically, the fluorescence assay these 
devices use to detect analyte is based on interrogation of the analyte by evanescence wave technology. Surface-bound molecules labeled with fluorophore are excited by an evanescent field, producing a fluorescent signal. A sandwich immunoassay format, consisting of capture antibody, analyte and labeled detection antibody, is used on the surface of the sensor. Since the penetration depth of the evanescent field is limited, only surface bound fluorophores are detected, thus enabling analysis in heterogeneous and turbid samples. Additionally, capture antibodies are easy to array on the detector, allowing for multiplexed detection of bacterial and other toxins.

Using this system, multiple biosensors were tested with BoNTs [98-103]. Sensitivities of the sensors range from $150 \mathrm{pg} / \mathrm{mL}\left(15 \mathrm{MLD}_{50} / \mathrm{mL}\right)$ for BoNT/E [100] to $200 \mathrm{ng} / \mathrm{mL}$ for BoNT/B [101] in buffers. Besides single analyte sensors, array sensors for multiple analytes were constructed for the simultaneous detection of several toxins such as BoNT/A, /B, cholera, ricin and staphylococcal endotoxin B, and bacterial samples [101,102]. Detection of BoNT/A toxoid in various food samples has been reported as well with sensitivities typically around $50 \mathrm{ng} / \mathrm{mL}$ [103]. Biosensor assays take only 10-20 minutes to complete, regardless of the number of analytes to be detected simultaneously. This makes it one of the fastest assays reported to date. But as in case of lateral flow devices, limited analytical sensitivity is the trade off for the speed.

Recently other biosensors relying on standard fluorescence assays [104,105] or optical immunoassays [106] have been reported. Interestingly, in one of the assays, the capture antibody was replaced by antimicrobial peptides with broad specificity for not only bacterial pathogens but also for bacterial toxins [105].

\section{Endopeptidase Activity Based Assays}

BoNTs are $\mathrm{Zn}^{2+}$-dependent endopeptidases that inhibit neurotransmitter release by specific cleavage of synaptic SNARE complex proteins. Exploitation of this endopeptidase role of BoNTs has led to numerous detection methods. Unlike the immunological in vitro methods described above which are unable to discriminate between an active and inactive form of the toxin, endopeptidase assays detect the active form only. For example, if food that was heated tested positive for the presence of BoNT by immunoassay, it may be negative by the mouse lethality assay and endopeptidase assays as the toxin may be inactive. In this sense, endopeptidase assays are closer to the mouse lethality bioassay than immunoassays. Detection of the active form is arguably more relevant because only the active form results in the associated morbidity and mortality.

Another advantage of endopeptidase assays is the inherent amplification of the signal by the catalytic cleavage reaction. In an endopeptidase activity assay, the actual analyte is the specific cleavage product rather than the toxin itself. The toxin concentration is then proportional to the concentration of the cleavage product. Because the cleavage process is catalytic and one molecule of the toxin can specifically cleave a large number of substrate molecules, an inherent amplification step is involved. This applies regardless of the actual method used for the detection of cleavage product.

On the other hand, endopeptidase assays are inherently more sensitive to sample matrix interference since toxin catalyzed cleavage of substrate is generally significantly less efficient in complex matrices. To overcome this problem, in some methods, toxin is captured from the matrix first, followed by performing the cleavage reaction in an optimized reaction buffer (see below). 


\section{Fluorescence Endopeptidase Assays}

A change in fluorescence of the substrate upon cleavage is often used to detect the endopeptidase activity of an enzyme. High-throughput fluorescence endopeptidase assays have been developed for detection of BoNT/A, /B, /E and /F. In this assay, a serotype-specific peptidic substrate labeled with fluorescein was chemically synthesized and immobilized on a solid support. After specific cleavage with one of the BoNTs, the peptide fragment labeled with fluorescein was released into the solution and spatially separated from uncleaved substrate for quantification [107]. This assay allowed detection of all four serotypes relevant to human botulism at concentrations as low as $2 \mathrm{ng} / \mathrm{mL}$ in microtiter plate format.

More recently, an assay based on the same principle (e.g., cleavage of a fluorophore labeled peptide from a solid support), but working in semiautomatic microfluidic format has been developed $[108,109]$. The microfluidic device (Figure 6) consists of two ports (input and detection) interconnected by a microchannel. The toxin sample is applied into the input port to catalyze the cleavage reaction of the fluorescein labeled peptide derived from sequence of SNAP-25 from the solid support. The cleaved fluorescein labeled fragment diffuses into the detection port designed to facilitate evaporation of the solution and effectively preconcentrate analyte before fluorescence detection. This evaporation led to 3-fold signal amplification over 35 minutes. The first generation device [109] used a fluorescent substrate tethered to silica beads but both intra- and inter-assay variation in bead load led to a decrease in sensitivity. In an improved second generation device [108] the substrate was tethered to a self-assembled monolayer on a gold surface and this device was able to detect as little as $3 \mathrm{pg} / \mathrm{mL}$ of BoNT/A (holotoxin) in buffer. Unfortunately, when tested in a complex matrix, the sensitivity dramatically decreased to $500 \mathrm{ng} / \mathrm{mL}$ of BoNT/A (holotoxin), suggesting that use for detection oftoxin in relevant matrices could be limited.

Figure 6. Microfluidic device for fluorescent endopeptidase assay. (A) Fluorescein labeled BoNT/A substrate attached through the linker to the gold surface. (B) View of the array of 40 devices (scale bar $=5 \mathrm{~mm}$ ). $(\mathrm{C})$ BoNT/A is added into input port. During incubation, immobilized substrate is cleaved and the fluorescent fragment is released into the solution and concentrated at the detection port via evaporation. Reprinted with permission from [108]. Copyright (C) 2009 American Chemical Society.

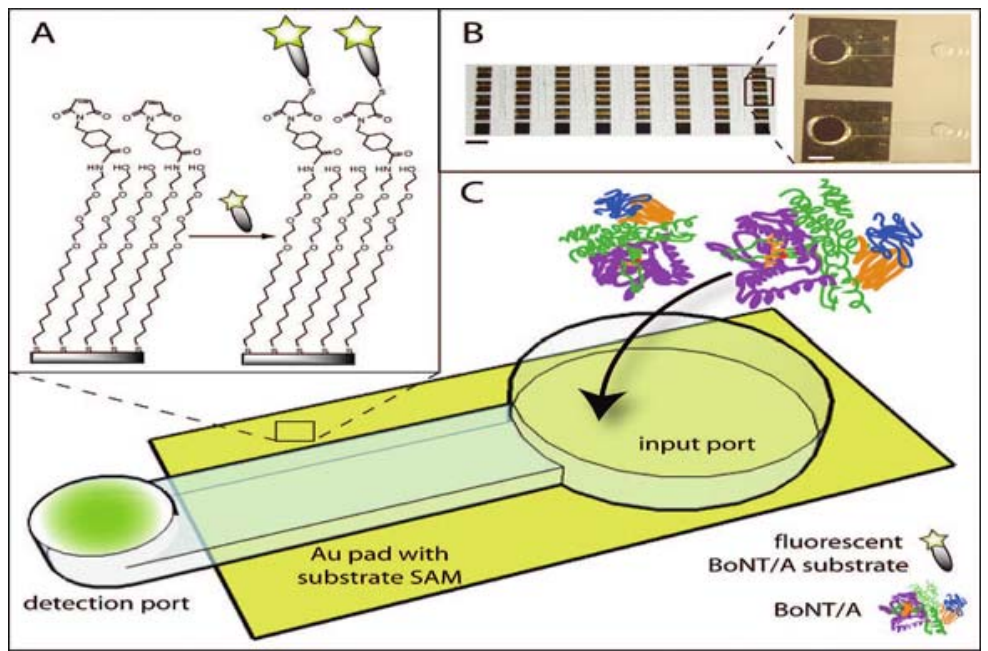




\section{FRET Endopeptidase Assays}

Another widely used technology for the detection of cleavage of peptide bonds is fluorescence resonance energy transfer (FRET). In one setup used for detection of BoNTs, an oligopeptide resembling natural substrate carries two tags flanking the cleavage site. One tag is the so called fluorescence quencher and other is a fluorescence donor. If they are close to each other in space, as in an uncleaved substrate, the fluorescence of an excited donor fluorophore is quenched (absorbed) by the quencher. However, once the substrate is cleaved and the quencher and donor fluorophore become separated, fluorescence of the donor is no longer quenched and can therefore be detected. Multiple variations of fluorophore/quencher modified substrates derived from SNAP-25 have been developed and used for the detection of BoNT/A [110-115]. Similarly, internally quenched fluorescent substrates derived from synaptobrevin and syntaxin have been developed [115]. The detection limit of direct FRET based assays depends on the particular FRET substrate used and range from $40 \mathrm{ng} / \mathrm{ml}$ of BoNT/A in apple juice or buffer [110,111] to $60 \mathrm{pg}$ of BoNT/A in buffer [113]. As in the case of other endopeptidase assays, food samples tested can severely interfere with the assay [110].

Alternatively, recombinant SNAP-25 or synaptobrevin with cyan fluorescent protein (CFP) and yellow fluorescent protein (YFP) at each side of the protein were employed as FRET substrates instead of chemically synthesized substrates [116-118]. The FRET between CFP/YFP pair is detected in the uncleaved protein but fluorescence is abolished once the substrate is cleaved. This CFP/YFP-SNAP25 sensor could detect $2 \mathrm{ng} / \mathrm{mL}$ of BoNT/A and /E in vitro; a synaptobrevin based sensor detected approximately $30 \mathrm{ng} / \mathrm{mL}$ of BoNT/B and /F in vitro within $4 \mathrm{~h}$ [116,117]. To further improve assay sensitivity, recombinant protein derived from SNAP-25 having one CFP donor in the middle of two substrate proteins with two YFP acceptors on each side was constructed, enhancing the capture of CFP emission in uncleaved protein and improving in vitro sensitivity to $0.3 \mathrm{ng} / \mathrm{mL}$ of BoNT/A [118]. Additionally, CFP/YFP sensors were transfected into PC12 cells and the toxin could be detected in living cells [116,117].

\subsection{FRET Assays with Immunocapture}

Crucial enhancement in the sensitivity of FRET based endopeptidase assays as well as a significant reduction of sample matrix interference was achieved by coupling the assay with an immunoseparation step (Figure 7) [112,114]. In this setup, the toxin is first captured from the sample by beads with toxin specific antibodies. The beads with captured toxin are subsequently resuspended in endopeptidase reaction buffer containing the synthetic FRET substrate to initiate the cleavage reaction. Importantly, the capture antibody utilized must be selected so as not to interfere with the catalytic function of bound BoNT. This system has several advantages: (i) the immunoseparation step eliminates/decreases interference from the matrix by separating the toxin from other sample containing nonspecific proteases, (ii) beads with toxin are resuspended in an optimal cleavage buffer, considerably increasing the efficiency of the cleavage reaction, (iii) toxin can be effectively concentrated by minimizing the volume of the cleavage reaction. This immunoseparation coupled FRET assay has been reported to have the impressive sensitivity of about $1 \mathrm{fg} / \mathrm{mL}$ (BoNT/A complex in buffer) which is five orders of magnitude more sensitive than the mouse lethality assay [112]. Comparable sensitivity in a limited 
number of matrices (e.g., serum, carrot juice, milk) has also been demonstrated. It is clearly the most sensitive assay reported, and only its application to more complex matrices will show if it is robust enough for widespread implementation.

Figure 7. (A) Diagram for the preparation of an immuno-affinity matrix for BoNT enrichment. Protein A beads are coupled to anti-BoNT antibodies and crosslinked via the Fc domain with disuccinimidyl suberate. Non-crosslinked antibodies are washed out. (B) Immobilized BoNT/A cleaves FRET substrate restoring fluorescence. Reprinted from [112], Copyright (C) 2008 the authors.

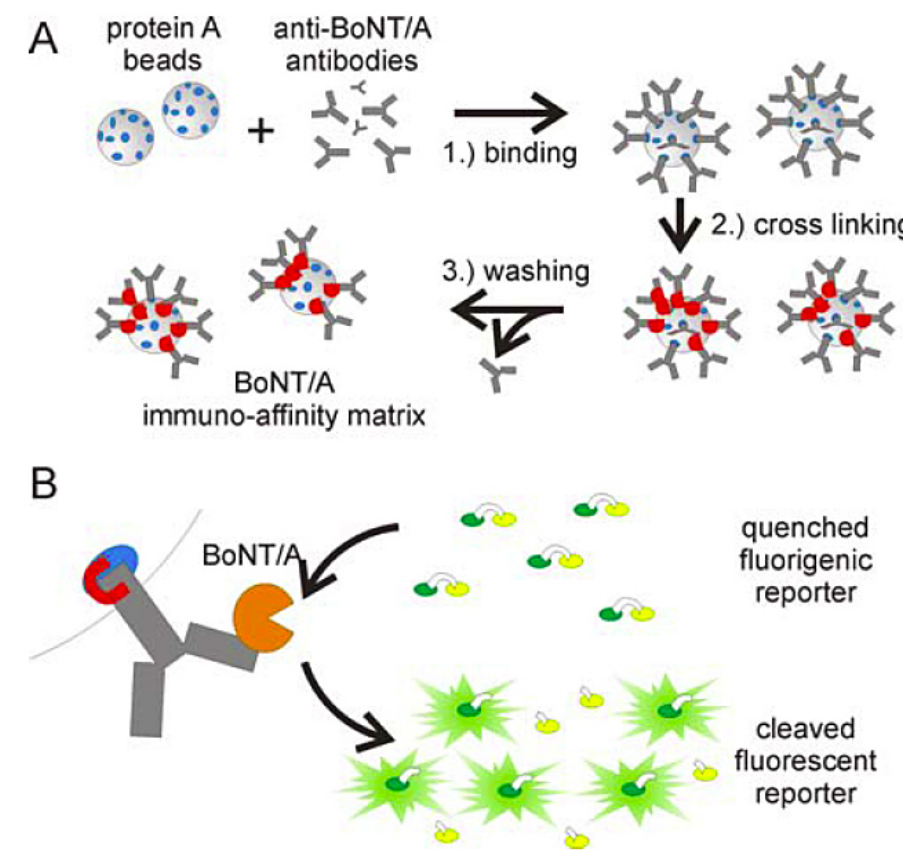

\section{Immunodetection of Cleavage Product}

Immunological detection of proteolytically generated SNARE protein (or synthetic analogue) cleavage products has been used in several assays. Typically, a chemically synthesized peptide substrate, derived from one of the SNARE protein sequences, is immobilized on a solid support and then treated with the toxin. The resulting cleavage product on the support is subsequently detected by cleavage product specific antibodies. Cleavage of SNAP-25 derived substrates was used for the detection of BoNT/A [119-121], BoNT/C1 [122], and BoNT/E [120]; cleavage of synaptobrevin has also been utilized for the detection of BoNT/B and its light chain [119,123]. Detection limits of this type of assay range from $200 \mathrm{pg} / \mathrm{mL}$ (BoNT/B) [119] to as low as $40 \mathrm{fg} / \mathrm{mL}$ (BoNT/A) [120]. However, all detections were performed in optimized reaction buffers. Detection of the toxin in relevant matrices was not demonstrated, but a significant decrease in sensitivity can be expected due to suboptimal cleavage conditions. It has also been demonstrated that the antibodies involved are able to adequately discriminate among the serotype specific cleavage products, suggesting that the assay can be used as a highly specific in vitro serotyping method [122].

To overcome matrix interference with the endopeptidase assay, immunoseparation of BoNT/B from the matrix, analogous to that employed in FRET assays, was developed [124]. BoNT/B sample was 
first applied onto an immunoaffinity column and the matrix was washed out after a short incubation. Biotin-modified substrate in reaction buffer was then applied onto the column and incubated to allow the cleavage to occur. Cleavage product specific antibodies were used for detection of the product upon elution from the column and immobilization on a streptavidin-coated plate. Using this system, $1 \mathrm{MLD}_{50}$ of BoNT/B was dectectable in a limited number of food samples [124].

In another report, BoNT/A1, /A2, /A3, /B1 and /F were captured from media by brain synaptosomes before incubation with an appropriate substrate. Serotype specific cleavage products were detected by ELISA with sensitivities from 0.5 to $10 \mathrm{MLD}_{50} / \mathrm{mL}$ in buffer or diluted sera and with limited sensitivity in food [125]. The method has its disadvantages: rat brain isolated synaptosomes are not a readily available reagent and differences in sensitivity with and without capture were not clearly demonstrated. However, in this report, synaptosome binding is more of a selection for holotoxin with the correct fold than a separation procedure in that only toxin with functional heavy chain binds. This ability to discriminate to some extent between functional light chain only and functional holotoxin makes this method unique among in vitro assays.

\section{Endopep-MS}

A method using mass spectrometry (MS) for the detection of the SNARE cleavage products has been developed at the US CDC; the assay has been called Endopep-MS assay [126,127]. Mass spectrometry in tandem with liquid chromatography can be used not only for the quantification of the toxin, but it is also able to differentiate all seven toxin serotypes by discriminating between each serotype's unique cleavage product(s). The detection limits achieved a range from 0.039 to $0.625 \mathrm{MLD}_{50} / \mathrm{mL}$ for BoNT/A, /B, /E and /F in a buffer [126]. However, the sensitivity of the method in serum and stool samples was not as impressive. To enhance the sensitivity of the assay in these and other complex matrices, an antibody capture step for toxin concentration, as well as separation from other nonspecific proteases from the matrix, was introduced [128,129]. Separation/concentration increased the sensitivity of the method by up to two orders of magnitude in reaction buffer and allowed detection of BoNT/A, /B, /E, and /F with sensitivities of $0.1-10 \mathrm{MLD}_{50} / \mathrm{mL}$ in sera samples and 0.5-100 $\mathrm{MLD}_{50} / \mathrm{mL}$ in stool samples [128]. In order to further expand the identification of serotypes to the identification of subtypes, the authors analyzed samples by means of mass spectrometry after a trypsin digest [130]. As identification of the subtype requires the analysis of the toxin protein itself, significantly more material is needed for the assay (about $2 \mu \mathrm{g}$ of the toxin).

The endopep-MS assay combined with antibody capture represents a very sensitive detection platform, with the additional advantage of serotype identification in one experiment. Together with the immunodetection of the cleavage product, these are the only two procedures able to detect the active toxin and discriminate between serotypes in a single experiment. However, a liquid chromatography system coupled with a mass spectromether is not available in every laboratory and is certainly less common than the simple plate readers required for quantification of signal from an immunodetection experiment. 


\section{Emerging in Vitro Assays and Technologies}

Aptamers are single stranded nucleic acids (DNA or RNA) selected from large nucleic acid libraries and used to bind specific targets such as small molecules or proteins, making them suitable for analytical and other applications [131]. Like antibodies, aptamers have a defined three dimensional structure that allows for specific interaction with the target. Additionally, they are faster and easier to select from a library of binders compared to immunoreagents, and once the sequence of aptamer is known, it can be easily chemically synthesized in high quantities.

BoNT/A detection methods based on structural changes of an aptamer upon binding to its target have been reported [132,133]. In one of the two reported methods [132], upon binding of BoNT/A to the aptamer, the aptamer can no longer assume the unbound three-dimensional conformation and is accessible to capture conjugated HRP used for amplification of the signal (Figure 8). The assay was able to detect toxoid at a concentration as low as $40 \mathrm{pg} / \mathrm{mL}$ in buffer. Unfortunately, the ionic composition of the detection buffer, and in particular, the potassium ion concentration present in the buffer had an enormous impact on assay performance. This can be attributed to the fact that the unbound aptamer contains a long G-quadruplex that is known to be stabilized by potassium ions.

Figure 8. Aptamer-based electrochemical detection of BoNT/A toxoid. Reprinted from [132] with kind permission from Springer Science+Business Media. Copyright (C) 2009 the authors.

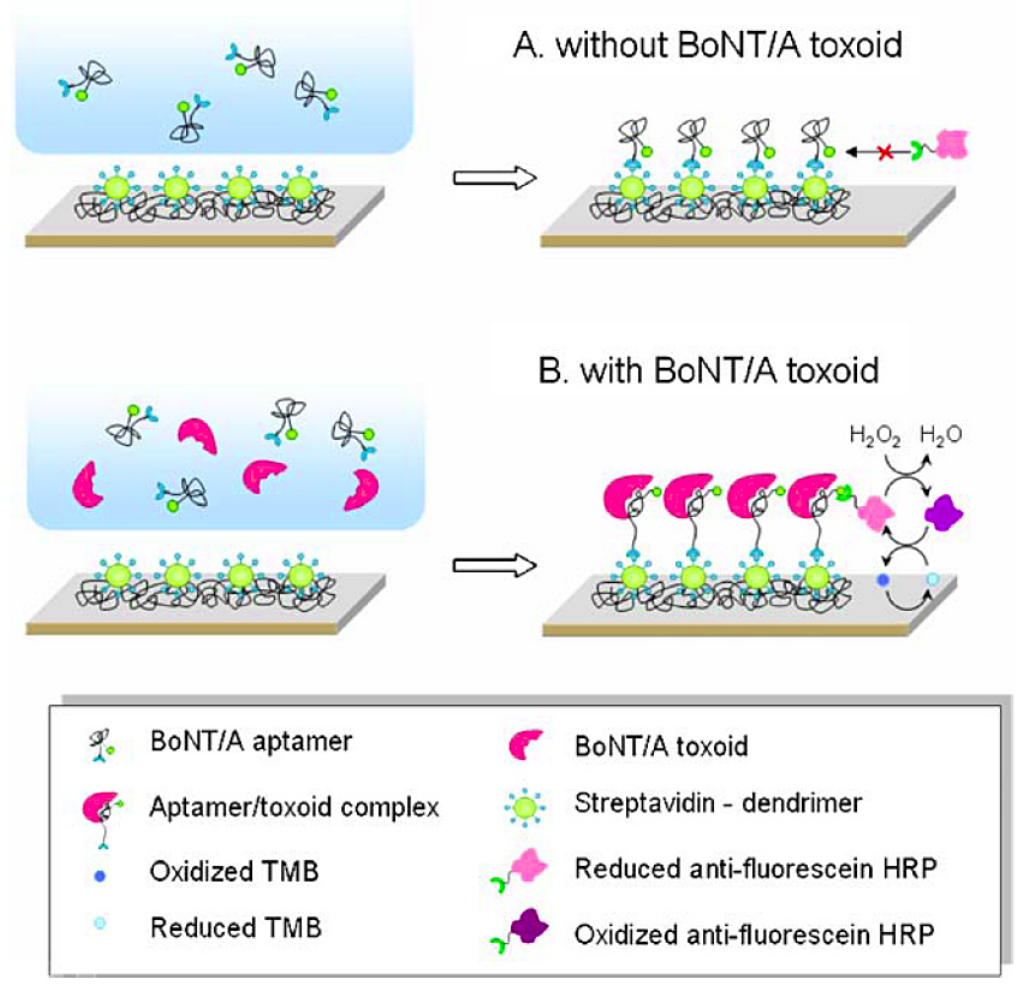

Microfluidic technology with chemical reactions, biochemical assays and biological processes performed on a chip on the micrometer scale has attracted enormous attention in the last decade. Indeed, detection of BoNT on microfluidic chips has been developed [134-136]. Assays carried out on a chip are miniaturized versions of the macroscopic assays described above, such as the sandwich type 
immunoassay [136] or FRET based endopeptidase assay [134,135]. There are clear advantages to microfluidic technology, including a reduction of reagent consumption and the ability to operate in a semiautomatic mode for all steps (e.g., sample preparation, pretreatment, mixing, incubation, washing) carried out on a chip. Particularly in the context of field deployment, there is huge promise to this technology.

In addition, there are various other techniques emerging as potential BoNT detection platforms. For example, surface plasmon resonance [137-139], rapid detection by transistors with gates modified by anti-toxin antibodies by change in drain-source current upon BoNT binding [140], liquid chromatography coupled to mass spectrometry [141], capillary electrophoresis [142], micromechanosensor able to detect synaptobrevin molecule cleavage by BoNT/B [143] or time resolved fluorescence assay [144]. Many of these techniques show promise but rely on expensive instrumentation and/or have not been sufficiently tested.

\section{Cell Based Assays}

Cell-based assays can be particularly valuable as diagnostics as they can recapitulate the natural environment experienced by an analyte more accurately, particularly when the analyte has a multistep activation mechanism, such as BoNTs. A FRET based cell assay (see above) has been developed [116,117], but this is not the only reported cell-based BoNT diagnostic. Another cell-based assay with fluorescence read-out has been reported recently [145]. Another interesting cell based assay is based on neural cultures grown on microelectrode arrays, which are used to record action potentials of the neural culture [146]. Toxin added into cell media then causes the changes in action potential signature of the culture. Cell based assays are good model for the study of all aspects of BoNT activity: cell surface receptor binding, endocytosis internalization, membrane translocation and finally SNARE cleavage. While in vitro activity assays only detect endopeptidase activity, the cleavage of the SNARE proteins in a cell occurs as the last step of this cascade. This makes these cell based assays and the others [147] ideal for BoNT inhibitor screens. However, their sensitivity in comparison to both mouse assay and in vitro assays is limited (usually in $\mathrm{ng} / \mathrm{mL}$ range) and it is difficult to obtain quantitative results. Furthermore, compared to in vitro methods, cell based assays are slow (days for detection), experimentally more demanding and require the maintenance of cell cultures. All of this makes them less suitable for routine toxin detection.

\section{Summary and Outlook}

In recent years, the development of in vitro assays for BoNT detection has accelerated, decreasing the limit of detection to femtogram per milliliter range (Table 1). However, none of the assays developed to date has been validated to be robust enough to completely replace the mouse lethality assay, the FDA-approved standard of BoNT detection. Although there are assays having sufficient sensitivity and specificity in simple buffer systems, these characteristics dramatically change when these assays are employed in BoNT detection in complex matrices such as food and clinical samples. 
Table 1. Summary of BoNT detection techniques.

\begin{tabular}{|c|c|c|c|c|c|}
\hline Method & Detection limit & $\begin{array}{l}\text { Analysis } \\
\text { time }\end{array}$ & Multiplex & Automation & $\begin{array}{l}\text { Matrix } \\
\text { interference }\end{array}$ \\
\hline Mouse lethality assay & $\begin{array}{l}1 \mathrm{MLD}_{50} \\
(20 \mathrm{pg} / \mathrm{mL} \text { BoNT/A) }\end{array}$ & 4-6 days & no & no & low \\
\hline ELISA & $5 \mathrm{pg} / \mathrm{mL}-2 \mathrm{ng} / \mathrm{mL}$ & 5-6 hours & limited & limited & manageable \\
\hline Flow cytometric assay & $50 \mathrm{pg} / \mathrm{mL}-20 \mathrm{ng} / \mathrm{mL}$ & 4 hours & yes & yes & manageable \\
\hline Electrochemiluminescence immunoassay & $5 \mathrm{pg} / \mathrm{mL}-50 \mathrm{ng} / \mathrm{mL}$ & 1 hour & limited & limited & manageable \\
\hline Immuno-PCR & $1-5 \mathrm{pg} / \mathrm{mL}$ & $6-9$ hours & limited & no & manageable \\
\hline Liposome-PCR & $0.02 \mathrm{fg} / \mathrm{mL}$ & 7-9 hours & limited & no & N/A \\
\hline Lateral flow test & $5-50 \mathrm{ng} / \mathrm{mL}$ & $15 \mathrm{~min}$ & no & - & high \\
\hline Biosensor (evanescence wave based) & $150 \mathrm{pg} / \mathrm{mL}-200 \mathrm{ng} / \mathrm{mL}$ & $10 \mathrm{~min}$ & yes & yes & low \\
\hline Fluorescence endopeptidase assay & $3 \mathrm{pg} / \mathrm{mL}$ & 3 hours & no & on-chip & high \\
\hline FRET endopeptidase assay & $60 \mathrm{pg} / \mathrm{mL}-40 \mathrm{ng} / \mathrm{mL}$ & 3 hours & no & no & high \\
\hline $\begin{array}{l}\text { FRET endopeptidase assay with } \\
\text { immunoseparation }\end{array}$ & $1 \mathrm{fg} / \mathrm{mL}$ & 2.5 hours & no & no & low \\
\hline Immuno-detection of cleavage product & $40 \mathrm{fg} / \mathrm{mL}-200 \mathrm{pg} / \mathrm{mL}$ & 6 hours & limited & no & high \\
\hline Endopep-MS & $0.4-6 \mathrm{pg} / \mathrm{mL}$ & 3-4 hours & yes & yes & high \\
\hline Cell based assay & $1-10 \mathrm{ng} / \mathrm{mL}$ & 2-3 days & no & no & low \\
\hline
\end{tabular}

If one was to postulate the characteristics of an "ideal" BoNT diagnostic, a number of features can be readily identified. It is clear that this assay must have at least the sensitivity of the mouse lethality assay, have minimal interference with complex matrices, have suitable throughput and be fast (e.g., performed in less than $1 \mathrm{~h}$ ). The need for a rapid assay is particularly important in cases of suspected clinical botulism, when fast action is needed to fight disease development. In this scenario, even the mouse lethality assay is not rapid enough. A successful assay would also allow for toxin serotype identification in the same experiment as toxin quantification, such as some types of immunoassays using serotype specific antibodies, endopep-MS or assays with immunodetection of the toxin cleavage product. Multiplexed identification of several toxins simultaneously with their serotypes and full automation of the assay is a further desirable extension beyond this. Additionally, an assay that can distinguish active and inactive forms of the toxin and quantify both would be advantageous since depending on the circumstances, detection of one form over the other may be beneficial. For example, activity of the toxin in older samples can diminish and give false negative results in activity assays, including the mouse lethality assay. On the other hand, as only active toxin can cause botulism, detection based on activity is of great clinical importance. It is likely that to get information about both active and inactive toxin, two independent assays will be needed. Lastly, a technology compatible with a hand-held type of device, or at least portable device, is essential for field deployment as in the scenario of a response to a bioterrorist attack.

These requirements are difficult to match and even the mouse lethality assay that has been used for decades does not fulfill all of the requirements of an "ideal” assay. To eliminate or minimize the effect of the matrix on assay performance has proven quite difficult in a number of technologies; in order to match this requirement, a given in vitro assay must perform with minimal variation under a wide 
variety of suboptimal conditions associated with a large range of sample matrices. Clearly, in all cases using the current technology available for BoNT detection, more research is required to validate the methods with a variety of complex matrices.

Tremendous progress has been made in the development of BoNT diagnostics and while the developed assays to date may not yet be fully validated, a set of capable alternatives to the mouse lethality assay are now available. While there is no single method that fulfills all the requirements of an ideal assay, individual methods have been developed that can address varying aspects of these requirements, allowing one to find the right assay for a given scenario.

\section{Acknowledgements}

We gratefully acknowledge the financial support of the National Institute of Health (NIH) Grant (AI082190).

\section{References}

1. Schantz, E.J.; Johnson, E.A. Properties and use of botulinum toxin and other microbial neurotoxins in medicine. Microbiol. Rev. 1992, 56, 80-99.

2. Dembek, Z.F.; Smith, L.A.; Rusnak, J.M. Botulism: Cause, effects, diagnosis, clinical and laboratory identification, and treatment modalities. Disaster Med. Public Health Prep. 2007, 1, 122-134.

3. Schiavo, G.; Matteoli, M.; Montecucco, C. Neurotoxins affecting neuroexocytosis. Physiol. Rev. 2000, 80, 717-766.

4. Shukla, H.D.; Sharma, S.K. Clostridium botulinum: A bug with beauty and weapon. Crit. Rev. Microbiol. 2005, 31, 11-18.

5. Arnon, S.S.; Schechter, R.; Inglesby, T.V.; Henderson, D.A.; Bartlett, J.G.; Ascher, M.S.; Eitzen, E.; Fine, A.D.; Hauer, J.; Layton, M.; Lillibridge, S.; Osterholm, M.T.; O'Toole, T.; Parker, G.; Perl, T.M.; Russell, P.K.; Swerdlow, D.L.; Tonat, K. Botulinum toxin as a biological weapon: Medical and public health management. JAMA 2001, 285, 1059-1070.

6. CDC Bioterrorism Agents/Diseases. Available online: http://www.bt.cdc.gov/agent/agentlistcategory.asp/ (Accessed on 7 January 2010).

7. Kostrzewa, R.M.; Segura-Aguilar, J. Botulinum neurotoxin: Evolution from poison, to research tool-onto medicinal therapeutic and future pharmaceutical panacea. Neurotox. Res. 2007, 12, 275-290.

8. Savino, P.J.; Maus, M. Botulinum toxin therapy. Neurol. Clin. 1991, 9, 205-224.

9. Eubanks, L.M.; Dickerson, T.J. Investigating novel therapeutic targets and molecular mechanisms to treat botulinum neurotoxin A intoxication. Future Microbiol. 2007, 2, 677-687.

10. Oguma, K.; Fujinaga, Y.; Inoue, K. Structure and function of Clostridium botulinum toxins. Microbiol. Immunol. 1995, 39, 161-168.

11. Simpson, L.L. Identification of the major steps in botulinum toxin action. Annu. Rev. Pharmacol. Toxicol. 2004, 44, 167-193.

12. Rummel, A.; Hafner, K.; Mahrhold, S.; Darashchonak, N.; Holt, M.; Jahn, R.; Beermann, S.; Karnath, T.; Bigalke, H.; Binz, T. Botulinum neurotoxins C, E and F bind gangliosides via a 
conserved binding site prior to stimulation-dependent uptake with botulinum neurotoxin $\mathrm{F}$ utilising the three isoforms of SV2 as second receptor. J. Neurochem. 2009, 110, 1942-1954.

13. Dong, M.; Yeh, F.; Tepp, W.H.; Dean, C.; Johnson, E.A.; Janz, R.; Chapman, E.R. SV2 is the protein receptor for botulinum neurotoxin A. Science 2006, 312, 592-596.

14. Fischer, A.; Mushrush, D.J.; Lacy, D.B.; Montal, M. Botulinum neurotoxin devoid of receptor binding domain translocates active protease. PLoS Pathog. 2008, 4, 245.

15. Fischer, A.; Montal, M. Single molecule detection of intermediates during botulinum neurotoxin translocation across membranes. Proc. Natl. Acad. Sci. USA 2007, 104, 10447-10452.

16. Schiavo, G.; Benfenati, F.; Poulain, B.; Rossetto, O.; Polverino de Laureto, P.; DasGupta, B.R.; Montecucco, C. Tetanus and botulinum-B neurotoxins block neurotransmitter release by proteolytic cleavage of synaptobrevin. Nature 1992, 359, 832-835.

17. Breidenbach, M.A.; Brunger, A.T. Substrate recognition strategy for botulinum neurotoxin serotype A. Nature 2004, 432, 925-929.

18. Blasi, J.; Chapman, E.R.; Link, E.; Binz, T.; Yamasaki, S.; Decamilli, P.; Sudhof, T.C.; Niemann, H.; Jahn, R. Botulinum neurotoxin A selectively cleaves the synaptic protein SNAP25. Nature 1993, 365, 160-163.

19. Rowland, L.P. Stroke, spasticity, and botulinum toxin. N. Engl. J. Med. 2002, 347, 382-383.

20. Sobel, J.; Tucker, N.; Sulka, A.; McLaughlin, J.; Maslanka, S. Foodborne botulism in the United States, 1990-2000. Emerg. Infect. Dis. 2004, 10, 1606-1611.

21. Cooper, J.G.; Spilke, C.E.; Denton, M.; Jamieson, S. Clostridium botulinum: An increasing complication of heroin misuse. Eur. J. Emerg. Med. 2005, 12, 251-252.

22. Kongsaengdao, S.; Samintarapanya, K.; Rusmeechan, S.; Wongsa, A.; Pothirat, C.; Permpikul, C.; Pongpakdee, S.; Puavilai, W.; Kateruttanakul, P.; Phengtham, U.; Panjapornpon, K.; Janma, J.; Piyavechviratana, K.; Sithinamsuwan, P.; Deesomchok, A.; Tongyoo, S.; Vilaichone, W.; Boonyapisit, K.; Mayotarn, S.; Piya-Isragul, B.; Rattanaphon, A.; Intalapaporn, P.; Dusitanond, P.; Harnsomburana, P.; Laowittawas, W.; Chairangsaris, P.; Suwantamee, J.; Wongmek, W.; Ratanarat, R.; Poompichate, A.; Panyadilok, H.; Sutcharitchan, N.; Chuesuwan, A.; Oranrigsupau, P.; Sutthapas, C.; Tanprawate, S.; Lorsuwansiri, J.; Phattana, N. An outbreak of botulism in Thailand: Clinical manifestations and management of severe respiratory failure. Clin. Infect. Dis. 2006, 43, 1247-1256.

23. Cai, S.; Singh, B.R.; Sharma, S. Botulism diagnostics: From clinical symptoms to in vitro assays. Crit. Rev. Microbiol. 2007, 33, 109-125.

24. Lindstrom, M.; Korkeala, H. Laboratory diagnostics of botulism. Clin. Microbiol. Rev. 2006, 19, 298-314.

25. Sharma, S.K.; Whiting, R.C. Methods for detection of Clostridium botulinum toxin in foods. $J$. Food Prot. 2005, 68, 1256-1263.

26. Solomon, H.M.; Lilly, T.J. Clostridium botulinum. In Bacteriological analytical manual, 8th Ed.; US Food and Drug Administration: Silver Spring, MD, USA, 2001.

27. Ferreira, J.L. Comparison of amplified ELISA and mouse bioassay procedures for determination of botulinal toxins A, B, E, and F. J. AOAC Int. 2001, 84, 85-88. 
28. Solberg, M.; Post, L.S.; Furgang, D.; Graham, C. Bovine serum eliminates rapid nonspecific toxic reactions during bioassay of stored fish for Clostridium botulinum toxin. Appl. Environ. Microbiol. 1985, 49, 644-649.

29. Dezfulian, M.; Bartlett, J.G. Detection of Clostridium botulinum type B toxin in the presence of a lethal substance interfering with toxin neutralization. Diagn. Microbiol. Infect. Dis. 1985, 3, 105-112.

30. Takahashi, M.; Kameyama, S.; Sakaguchi, G. Assay in mice for low levels of Clostridium botulinum toxin. Int. J. Food Microbiol. 1990, 11, 271-277.

31. Sesardic, D.; McLellan, K.; Ekong, T.A.; Das, R.G. Refinement and validation of an alternative bioassay for potency testing of therapeutic botulinum type A toxin. Pharmacol. Toxicol. 1996, 78, 283-288.

32. Boroff, D.A.; Fleck, U. Statistical analysis of a rapid in vivo method for the titration of the toxin of Clostridium botulinum. J. Bacteriol. 1966, 92, 1580-1581.

33. Torii, Y.; Goto, Y.; Takahashi, M.; Ishida, S.; Harakawa, T.; Sakamoto, T.; Kaji, R.; Kozaki, S.; Ginnaga, A. Quantitative determination of biological activity of botulinum toxins utilizing compound muscle action potentials (CMAP), and comparison of neuromuscular transmission blockage and muscle flaccidity among toxins. Toxicon 2009. 407-414.

34. Sheridan, R.E.; Deshpande, S.S.; Smith, T. Comparison of in vivo and in vitro mouse bioassays for botulinum toxin antagonists. J. Appl. Toxicol. 1999, 19, S29-S33.

35. Adler, M.; Scovill, J.; Parker, G.; Lebeda, F.J.; Piotrowski, J.; Deshpande, S.S. Antagonism of botulinum toxin-induced muscle weakness by 3,4-diaminopyridine in rat phrenic nervehemidiaphragm preparations. Toxicon 1995, 33, 527-537.

36. Deshpande, S.S.; Sheridan, R.E.; Adler, M. A study of zinc-dependent metalloendopeptidase inhibitors as pharmacological antagonists in botulinum neurotoxin poisoning. Toxicon 1995, 33, 551-557.

37. Scarlatos, A.; Welt, B.A.; Cooper, B.Y.; Archer, D.; DeMarse, T.; Chau, K.V. Methods for detecting botulinum toxin with applicability to screening foods against biological terrorist attacks. J. Food Sci. 2005, 70, R121-R130.

38. Boroff, D.A.; Chu-Chen, G. Radioimmunoassay for type A toxin of Clostridium botulinum. Appl. Microbiol. 1973, 25, 545-549.

39. Ashton, A.C.; Crowther, J.S.; Dolly, J.O. A sensitive and useful radioimmunoassay for neurotoxin and its haemagglutinin complex from Clostridium botulinum. Toxicon 1985, 23, 235-246.

40. Johnson, H.M.; Brenner, K.; Angelotti, R.; Hall, H.E. Serological studies of types A, B, and E botulinal toxins by passive hemagglutination and bentonite flocculation. J. Bacteriol. 1966, 91, 967-974.

41. Ferreira, J.L.; Hamdy, M.K.; Zapatka, F.A.; Hebert, W.O. Immunodiffusion method for detection of type A Clostridium botulinum. Appl. Environ. Microbiol. 1981, 42, 1057-1061.

42. Miller, C.A.; Anderson, A.W. Rapid detection and quantitative estimation of type A botulinum toxin by electroimmunodiffusion. Infect. Immun. 1971, 4, 126-129.

43. Mestrandrea, L.W. Rapid detection of Clostridium botulinum toxin by capillary tube diffusion. Appl. Microbiol. 1974, 27, 1017-1022. 
44. Vermilyea, B.L.; Walker, H.W.; Ayres, J.C. Detection of botulinal toxins by immunodiffusion. Appl. Microbiol. 1968, 16, 21-24.

45. Notermans, S.; Dufrenne, J.; Schothorst, M. Enzyme-linked immunosorbent assay for detection of Clostridium botulinum toxin type A. Jpn. J. Med. Sci. Biol. 1978, 31, 81-85.

46. Kozaki, S.; Dufrenne, J.; Hagenaars, A.M.; Notermans, S. Enzyme linked immunosorbent assay (ELISA) for detection of Clostridium botulinum type B toxin. Jpn. J. Med. Sci. Biol. 1979, 32, 199-205.

47. Notermans, S.; Dufrenne, J.; Kozaki, S. Enzyme-linked immunosorbent assay for detection of Clostridium botulinum type E toxin. Appl. Environ. Microbiol. 1979, 37, 1173-1175.

48. Stanker, L.H.; Merrill, P.; Scotcher, M.C.; Cheng, L.W. Development and partial characterization of high-affinity monoclonal antibodies for botulinum toxin type A and their use in analysis of milk by sandwich ELISA. J. Immunol. Methods. 2008, 336, 1-8.

49. Poli, M.A.; Rivera, V.R.; Neal, D. Development of sensitive colorimetric capture ELISAs for Clostridium botulinum neurotoxin serotypes E and F. Toxicon 2002, 40, 797-802.

50. Volland, H.; Lamourette, P.; Nevers, M.C.; Mazuet, C.; Ezan, E.; Neuburger, L.M.; Popoff, M.; Creminon, C. A sensitive sandwich enzyme immunoassay for free or complexed Clostridium botulinum neurotoxin type A. J. Immunol. Methods. 2008, 330, 120-129.

51. Szilagyi, M.; Rivera, V.R.; Neal, D.; Merrill, G.A.; Poli, M.A. Development of sensitive colorimetric capture elisas for Clostridium botulinum neurotoxin serotypes A and B. Toxicon 2000, 38, 381-389.

52. Ferreira, J.L.; Eliasberg, S.J.; Harrison, M.A.; Edmonds, P. Detection of preformed type A botulinal toxin in hash brown potatoes by using the mouse bioasssay and a modified ELISA test. J. AOAC Int. 2001, 84, 1460-1464.

53. Ferreira, J.L.; Maslanka, S.; Johnson, E.; Goodnough, M. Detection of botulinal neurotoxins A, $\mathrm{B}, \mathrm{E}$, and $\mathrm{F}$ by amplified enzyme-linked immunosorbent assay: Collaborative study. J. AOAC Int. 2003, 86, 314-331.

54. Ferreira, J.L.; Eliasberg, S.J.; Edmonds, P.; Harrison, M.A. Comparison of the mouse bioassay and enzyme-linked immunosorbent assay procedures for the detection of type A botulinal toxin in food. J. Food Prot. 2004, 67, 203-206.

55. Doellgast, G.J.; Triscott, M.X.; Beard, G.A.; Bottoms, J.D.; Cheng, T.; Roh, B.H.; Roman, M.G.; Hall, P.A.; Brown, J.E. Sensitive enzyme-linked immunosorbent assay for detection of Clostridium botulinum neurotoxins A, B, and E using signal amplification via enzyme-linked coagulation assay. J. Clin. Microbiol. 1993, 31, 2402-2409.

56. Doellgast, G.J.; Beard, G.A.; Bottoms, J.D.; Cheng, T.; Roh, B.H.; Roman, M.G.; Hall, P.A.; Triscott, M.X. Enzyme-linked immunosorbent assay and enzyme-linked coagulation assay for detection of Clostridium botulinum neurotoxins A, B, and E and solution-phase complexes with dual-label antibodies. J. Clin. Microbiol. 1994, 32, 105-111.

57. Roman, M.G.; Humber, J.Y.; Hall, P.A.; Reddy, N.R.; Solomon, H.M.; Triscott, M.X.; Beard, G.A.; Bottoms, J.D.; Cheng, T.; Doellgast, G.J. Amplified immunoassay ELISA-ELCA for measuring Clostridium-botulinum type-E neurotoxin in fish fillets. J. Food Prot. 1994, 57, 985-990. 
58. Smith, T.J.; Lou, J.; Geren, I.N.; Forsyth, C.M.; Tsai, R.; Laporte, S.L.; Tepp, W.H.; Bradshaw, M.; Johnson, E.A.; Smith, L.A.; Marks, J.D. Sequence variation within botulinum neurotoxin serotypes impacts antibody binding and neutralization. Infect. Immun. 2005, 73, 5450-5457.

59. Ekong, T.A.; McLellan, K.; Sesardic, D. Immunological detection of Clostridium botulinum toxin type A in therapeutic preparations. J. Immunol. Methods. 1995, 180, 181-191.

60. Ferreira, J.L.; Crawford, R.G. Detection of type a botulinal toxin-producing organisms subcultured from cheese using an amplified ELISA system. J. Rapid. Methods. Autom. Microbiol. 1998, 6, 289-296.

61. Dezfulian, M.; Bartlett, J.G. Detection of Clostridium botulinum type A toxin by enzyme-linked immunosorbent assay with antibodies produced in immunologically tolerant animals. J. Clin. Microbiol. 1984, 19, 645-648.

62. Dezfulian, M.; Bartlett, J.G. Selective isolation and rapid identification of Clostridium-botulinum type-A and type-B by toxin detection. J. Clin. Microbiol. 1985, 21, 231-233.

63. Sharma, S.K.; Ferreira, J.L.; Eblen, B.S.; Whiting, R.C. Detection of type A, B, E, and F Clostridium botulinum neurotoxins in foods by using an amplified enzyme-linked immunosorbent assay with digoxigenin-labeled antibodies. Appl. Environ. Microbiol. 2006, 72, 1231-1238.

64. Potter, M.D.; Meng, J.H.; Kimsey, P. An ELISA for detection of botulinal toxin type-A, type-B, and type-E in inoculated food samples. J. Food Prot. 1993, 56, 856-861.

65. Rodriguez, A.; Dezfulian, M. Rapid identification of Clostridium botulinum and botulinal toxin in food. Folia Microbiol. (Praha) 1997, 42, 149-151.

66. Dezfulian, M.; Hatheway, C.L.; Yolken, R.H.; Bartlett, J.G. Enzyme-linked immunosorbent assay for detection of Clostridium botulinum type A and type B toxins in stool samples of infants with botulism. J. Clin. Microbiol. 1984, 20, 379-383.

67. Ma, H.; Zhou, B.; Kim, Y.; Janda, K.D. A cyclic peptide-polymer probe for the detection of Clostridium botulinum neurotoxin serotype A. Toxicon 2006, 47, 901-908.

68. Singh, A.K.; Harrison, S.H.; Schoeniger, J.S. Gangliosides as receptors for biological toxins: Development of sensitive fluoroimmunoassays using ganglioside-bearing liposomes. Anal. Chem. 2000, 72, 6019-6024.

69. Fishman, P.H.; Pacuszka, T.; Orlandi, P.A. Gangliosides as receptors for bacterial enterotoxins. Adv. Lipid Res. 1993, 25, 165-187.

70. Holmgren, J.; Elwing, H.; Fredman, P.; Strannegard, O.; Svennerholm, L. Gangliosides as receptors for bacterial toxins and Sendai virus. Adv. Exp. Med. Biol. 1980, 125, 453-470.

71. Kitamura, M.; Iwamori, M.; Nagai, Y. Interaction between Clostridium botulinum neurotoxin and gangliosides. Biochim. Biophys. Acta. 1980, 628, 328-335.

72. Stenmark, P.; Dupuy, J.; Imamura, A.; Kiso, M.; Stevens, R.C. Crystal structure of botulinum neurotoxin type A in complex with the cell surface co-receptor GT1b-insight into the toxinneuron interaction. PLoS Pathog. 2008, 4, 129.

73. Warner, M.G.; Grate, J.W.; Tyler, A.; Ozanich, R.M.; Miller, K.D.; Lou, J.; Marks, J.D.; Bruckner-Lea, C.J. Quantum dot immunoassays in renewable surface column and 96-well plate formats for the fluorescence detection of botulinum neurotoxin using high-affinity antibodies. Biosens. Bioelectron. 2009, 25, 179-184. 
74. Grate, J.W.; Warner, M.G.; Ozanich, R.M., Jr.; Miller, K.D.; Colburn, H.A.; Dockendorff, B.; Antolick, K.C.; Anheier, N.C., Jr.; Lind, M.A.; Lou, J.; Marks, J.D.; Bruckner-Lea, C.J. Renewable surface fluorescence sandwich immunoassay biosensor for rapid sensitive botulinum toxin detection in an automated fluidic format. Analyst 2009, 134, 987-996.

75. Kwon, Y.; Hara, C.A.; Knize, M.G.; Hwang, M.H.; Venkateswaran, K.S.; Wheeler, E.K.; Bell, P.M.; Renzi, R.F.; Fruetel, J.A.; Bailey, C.G. Magnetic bead based immunoassay for autonomous detection of toxins. Anal. Chem. 2008, 80, 8416-8423.

76. Varnum, S.M.; Warner, M.G.; Dockendorff, B.; Anheier, N.C., Jr.; Lou, J.; Marks, J.D.; Smith, L.A.; Feldhaus, M.J.; Grate, J.W.; Bruckner-Lea, C.J. Enzyme-amplified protein microarray and a fluidic renewable surface fluorescence immunoassay for botulinum neurotoxin detection using high-affinity recombinant antibodies. Anal. Chim. Acta. 2006, 570, 137-143.

77. Ozanich, R.M., Jr.; Bruckner-Lea, C.J.; Warner, M.G.; Miller, K.; Antolick, K.C.; Marks, J.D.; Lou, J.; Grate, J.W. Rapid multiplexed flow cytometric assay for botulinum neurotoxin detection using an automated fluidic microbead-trapping flow cell for enhanced sensitivity. Anal. Chem. 2009, 81, 5783-5793.

78. Anderson, G.P.; Taitt, C.R. Amplification of microsphere-based microarrays using catalyzed reporter deposition. Biosens. Bioelectron. 2008, 24, 324-328.

79. Pauly, D.; Kirchner, S.; Stoermann, B.; Schreiber, T.; Kaulfuss, S.; Schade, R.; Zbinden, R.; Avondet, M.A.; Dorner, M.B.; Dorner, B.G. Simultaneous quantification of five bacterial and plant toxins from complex matrices using a multiplexed fluorescent magnetic suspension assay. Analyst 2009, 134, 2028-2039.

80. Gattomenking, D.L.; Yu, H.; Bruno, J.G.; Goode, M.T.; Miller, M.; Zulich, A.W. Sensitive detection of biotoxoids and bacterial spores using an immunomagnetic electrochemiluminescence sensor. Biosens. Bioelectron. 1995, 10, 501-507.

81. Guglielmo-Viret, V.; Attree, O.; Blanco-Gros, V.; Thullier, P. Comparison of electrochemiluminescence assay and ELISA for the detection of Clostridium botulinum type B neurotoxin. J. Immunol. Methods. 2005, 301, 164-172.

82. Rivera, V.R.; Gamez, F.J.; Keener, W.K.; White, J.A.; Poli, M.A. Rapid detection of Clostridium botulinum toxins A, B, E, and F in clinical samples, selected food matrices, and buffer using paramagnetic bead-based electrochemiluminescence detection. Anal. Biochem. 2006, 353, 248256.

83. Phillips, R.W.; Abbott, D. High-throughput enzyme-linked immunoabsorbant assay (ELISA) electrochemiluminescent detection of botulinum toxins in foods for food safety and defence purposes. Food Addit. Contam. Part A Chem. Anal. Control Expo. Risk Assess. 2008, 25, 10841088.

84. Sano, T.; Smith, C.L.; Cantor, C.R. Immuno-PCR: Very sensitive antigen detection by means of specific antibody-DNA conjugates. Science 1992, 258, 120-122.

85. Wu, H.C.; Huang, Y.L.; Lai, S.C.; Huang, Y.Y.; Shalo, M.F. Detection of Clostridium botulinum neurotoxin type A using immuno-PCR. Lett. Appl. Microbiol. 2001, 32, 321-325.

86. Chao, H.Y.; Wang, Y.C.; Tang, S.S.; Liu, H.W. A highly sensitive immuno-polymerase chain reaction assay for Clostridium botulinum neurotoxin type A. Toxicon 2004, 43, 27-34. 
87. Mason, J.T.; Xu, L.; Sheng, Z.M.; O'Leary, T.J. A liposome-PCR assay for the ultrasensitive detection of biological toxins. Nat. Biotechnol. 2006, 24, 555-557.

88. Mason, J.T.; Xu, L.; Sheng, Z.M.; He, J.; O'Leary, T.J. Liposome polymerase chain reaction assay for the sub-attomolar detection of cholera toxin and botulinum neurotoxin type A. Nat. Protoc. 2006, 1, 2003-2011.

89. Sharma, S.K.; Eblen, B.S.; Bull, R.L.; Burr, D.H.; Whiting, R.C. Evaluation of lateral-flow Clostridium botulinum neurotoxin detection kits for food analysis. Appl. Environ. Microbiol. 2005, 71, 3935-3941.

90. Attree, O.; Guglielmo-Viret, V.; Gros, V.; Thullier, P. Development and comparison of two immunoassay formats for rapid detection of botulinum neurotoxin type A. J. Immunol. Methods. 2007, 325, 78-87.

91. Gessler, F.; Pagel-Wieder, S.; Avondet, M.A.; Bohnel, H. Evaluation of lateral flow assays for the detection of botulinum neurotoxin type A and their application in laboratory diagnosis of botulism. Diagn. Microbiol. Infect. Dis. 2007, 57, 243-249.

92. Chiao, D.J.; Wey, J.J.; Shyu, R.H.; Tang, S.S. Monoclonal antibody-based lateral flow assay for detection of botulinum neurotoxin type A. Hybridoma. (Larchmt). 2008, 27, 31-35.

93. Han, S.M.; Cho, J.H.; Cho, I.H.; Paek, E.H.; Oh, H.B.; Kim, B.S.; Ryu, C.; Lee, K.; Kim, Y.K.; Paek, S.H. Plastic enzyme-linked immunosorbent assays (ELISA)-on-a-chip biosensor for botulinum neurotoxin A. Anal. Chim. Acta. 2007, 587, 1-8.

94. Chiao, D.J.; Shyu, R.H.; Hu, C.S.; Chiang, H.Y.; Tang, S.S. Colloidal gold-based immunochromatographic assay for detection of botulinum neurotoxin type B. J. Chromatogr. B. Analyt. Technol. Biomed. Life Sci. 2004, 809, 37-41.

95. Ahn-Yoon, S.; DeCory, T.R.; Durst, R.A. Ganglioside-liposome immunoassay for the detection of botulinum toxin. Anal. Bioanal. Chem. 2004, 378, 68-75.

96. Taitt, C.R.; Shriver-Lake, L.C.; Ngundi, M.M.; Ligler, F.S. Array Biosensor for Toxin Detection: Continued Advances. Sensors 2008, 8, 8361-8377.

97. Sapsford, K.E.; Shubin, Y.S.; Delehanty, J.B.; Golden, J.P.; Taitt, C.R.; Shriver-Lake, L.C.; Ligler, F.S. Fluorescence-based array biosensors for detection of biohazards. J. Appl. Microbiol. 2004, 96, 47-58.

98. Ogert, R.A.; Brown, J.E.; Singh, B.R.; Shriver-Lake, L.C.; Ligler, F.S. Detection of Clostridium botulinum toxin A using a fiber optic-based biosensor. Anal. Biochem. 1992, 205, 306-312.

99. Kumar, P.; Colston, J.T.; Chambers, J.P.; Rael, E.D.; Valdes, J.J. Detection of botulinum toxin using an evanescent wave immunosensor. Biosens. Bioelectron. 1994, 9, 57-63.

100. Singh, B.R.; Silvia, M.A. Detection of botulinum neurotoxins using optical fiber-based biosensor. Adv. Exp. Med. Biol. 1996, 391, 499-508.

101. Rowe-Taitt, C.A.; Golden, J.P.; Feldstein, M.J.; Cras, J.J.; Hoffman, K.E.; Ligler, F.S. Array biosensor for detection of biohazards. Biosens. Bioelectron. 2000, 14, 785-794.

102. Ligler, F.S.; Taitt, C.R.; Shriver-Lake, L.C.; Sapsford, K.E.; Shubin, Y.; Golden, J.P. Array biosensor for detection of toxins. Anal. Bioanal. Chem. 2003, 377, 469-477.

103. Sapsford, K.E.; Taitt, C.R.; Loo, N.; Ligler, F.S. Biosensor detection of botulinum toxoid A and staphylococcal enterotoxin B in food. Appl. Environ. Microbiol. 2005, 71, 5590-5592. 
104. Kostov, Y.; Sergeev, N.; Wilson, S.; Herold, K.E.; Rasooly, A. A simple portable electroluminescence illumination-based CCD detector. Methods Mol. Biol. 2009, 503, 259-272.

105. Kulagina, N.V.; Anderson, G.P.; Ligler, F.S.; Shaffer, K.M.; Taitt, C.R. Antimicrobial peptides: New recognition molecules for detecting botulinum toxins. Sensors 2007, 7, 2808-2824.

106. Ganapathy, R.; Padmanabhan, S.; Eric, Y.P.; Moochhala, S.; Lionel, L.K.; Ponnampalam, G. Rapid detection of botulinum neurotoxins A, B, E, and F by optical immunoassay. Front. Biosci. 2008, 13, 5432-5440.

107. Schmidt, J.J.; Stafford, R.G.; Millard, C.B. High-throughput assays for botulinum neurotoxin proteolytic activity: Serotypes A, B, D, and F. Anal. Biochem. 2001, 296, 130-137.

108. Frisk, M.L.; Tepp, W.H.; Johnson, E.A.; Beebe, D.J. Self-assembled peptide monolayers as a toxin sensing mechanism within arrayed microchannels. Anal. Chem. 2009, 81, 2760-2767.

109. Frisk, M.L.; Berthier, E.; Tepp, W.H.; Johnson, E.A.; Beebe, D.J. Bead-based microfluidic toxin sensor integrating evaporative signal amplification. Lab. Chip. 2008, 8, 1793-1800.

110. Rasooly, R.; Stanker, L.H.; Carter, J.M.; Do, P.M.; Cheng, L.W.; He, X.; Brandon, D.L. Detection of botulinum neurotoxin-A activity in food by peptide cleavage assay. Int. J. Food Microbiol. 2008, 126, 135-139.

111. Sapsford, K.E.; Sun, S.; Francis, J.; Sharma, S.; Kostov, Y.; Rasooly, A. A fluorescence detection platform using spatial electroluminescent excitation for measuring botulinum neurotoxin A activity. Biosens. Bioelectron. 2008, 24, 618-625.

112. Bagramyan, K.; Barash, J.R.; Arnon, S.S.; Kalkum, M. Attomolar detection of botulinum toxin type A in complex biological matrices. PLoS One. 2008, 3, 41.

113. Poras, H.; Ouimet, T.; Orng, S.V.; Fournie-Zaluski, M.C.; Popoff, M.R.; Roques, B.P. Detection and quantification of botulinum neurotoxin type a by a novel rapid in vitro fluorimetric assay. Appl. Environ. Microbiol. 2009, 75, 4382-4390.

114. Rasooly, R.; Do, P.M. Development of an in vitro activity assay as an alternative to the mouse bioassay for Clostridium botulinum neurotoxin type A. Appl. Environ. Microbiol. 2008, 74, 4309-4313.

115. Perpetuo, E.A.; Juliano, L.; Juliano, M.A.; Fratelli, F.; Prado, S.M.; Pimenta, D.C.; Lebrun, I. Enzymatic profiling of tetanus and botulinum neurotoxins based on vesicle-associated-membrane protein derived fluorogenic substrates. Protein Pept. Lett. 2008, 15, 1100-1106.

116. Dong, M.; Tepp, W.H.; Johnson, E.A.; Chapman, E.R. Using fluorescent sensors to detect botulinum neurotoxin activity in vitro and in living cells. Proc. Natl. Acad. Sci. USA 2004, 101, 14701-14706.

117. Parpura, V.; Chapman, E.R. Detection of botulinum toxins: Micromechanical and fluorescencebased sensors. Croat. Med. J. 2005, 46, 491-497.

118. Pires-Alves, M.; Ho, M.; Aberle, K.K.; Janda, K.D.; Wilson, B.A. Tandem fluorescent proteins as enhanced FRET-based substrates for botulinum neurotoxin activity. Toxicon 2009, 53, 392-399.

119. Hallis, B.; James, B.A.; Shone, C.C. Development of novel assays for botulinum type A and B neurotoxins based on their endopeptidase activities. J. Clin. Microbiol. 1996, 34, 1934-1938. 
120. Jones, R.G.; Ochiai, M.; Liu, Y.; Ekong, T.; Sesardic, D. Development of improved SNAP25 endopeptidase immuno-assays for botulinum type A and E toxins. J. Immunol. Methods. 2008, 329, 92-101.

121. Ekong, T.A.; Feavers, I.M.; Sesardic, D. Recombinant SNAP-25 is an effective substrate for Clostridium botulinum type A toxin endopeptidase activity in vitro. Microbiology 1997, 143, 3337-3347.

122. Jones, R.G.; Liu, Y.; Sesardic, D. New highly specific botulinum type C1 endopeptidase immunoassays utilising SNAP25 or Syntaxin substrates. J. Immunol. Methods. 2009, 343, 21-27.

123. Kegel, B.; Behrensdorf-Nicol, H.A.; Bonifas, U.; Silberbach, K.; Klimek, J.; Kramer, B.; Weisser, K. An in vitro assay for detection of tetanus neurotoxin activity: Using antibodies for recognizing the proteolytically generated cleavage product. Toxicol. In Vitro. 2007, 21, 1641-1649.

124. Wictome, M.; Newton, K.; Jameson, K.; Hallis, B.; Dunnigan, P.; Mackay, E.; Clarke, S.; Taylor, R.; Gaze, J.; Foster, K.; Shone, C. Development of an in vitro bioassay for Clostridium botulinum type B neurotoxin in foods that is more sensitive than the mouse bioassay. Appl. Environ. Microbiol. 1999, 65, 3787-3792.

125. Evans, E.R.; Skipper, P.J.; Shone, C.C. An assay for botulinum toxin types A, B and F that requires both functional binding and catalytic activities within the neurotoxin. J. Appl. Microbiol. 2009, 107, 1384-1391.

126. Boyer, A.E.; Moura, H.; Woolfitt, A.R.; Kalb, S.R.; McWilliams, L.G.; Pavlopoulos, A.; Schmidt, J.G.; Ashley, D.L.; Barr, J.R. From the mouse to the mass spectrometer: Detection and differentiation of the endoproteinase activities of botulinum neurotoxins A-G by mass spectrometry. Anal. Chem. 2005, 77, 3916-3924.

127. Barr, J.R.; Moura, H.; Boyer, A.E.; Woolfitt, A.R.; Kalb, S.R.; Pavlopoulos, A.; McWilliams, L.G.; Schmidt, J.G.; Martinez, R.A.; Ashley, D.L. Botulinum neurotoxin detection and differentiation by mass spectrometry. Emerg. Infect. Dis. 2005, 11, 1578-1583.

128. Kalb, S.R.; Moura, H.; Boyer, A.E.; McWilliams, L.G.; Pirkle, J.L.; Barr, J.R. The use of Endopep-MS for the detection of botulinum toxins A, B, E, and F in serum and stool samples. Anal. Biochem. 2006, 351, 84-92.

129. Gaunt, P.S.; Kalb, S.R.; Barr, J.R. Detection of botulinum type E toxin in channel catfish with visceral toxicosis syndrome using catfish bioassay and endopep mass spectrometry. J. Vet. Diagn. Invest. 2007, 19, 349-354.

130. Kalb, S.R.; Goodnough, M.C.; Malizio, C.J.; Pirkle, J.L.; Barr, J.R. Detection of botulinum neurotoxin A in a spiked milk sample with subtype identification through toxin proteomics. Anal. Chem. 2005, 77, 6140-6146.

131. Tombelli, S.; Mascini, M. Aptamers as molecular tools for bioanalytical methods. Curr. Opin. Mol. Ther. 2009, 11, 179-188.

132. Wei, F.; Ho, C.M. Aptamer-based electrochemical biosensor for Botulinum neurotoxin. Anal. Bioanal. Chem .2009, 393, 1943-1948.

133. Fan, M.; McBurnett, S.R.; Andrews, C.J.; Allman, A.M.; Bruno, J.G.; Kiel, J.L. Aptamer selection express: A novel method for rapid single-step selection and sensing of aptamers. $J$. Biomol. Tech. 2008, 19, 311-319. 
134. Sun, S.; Ossandon, M.; Kostov, Y.; Rasooly, A. Lab-on-a-chip for botulinum neurotoxin a (BoNT-A) activity analysis. Lab. Chip. 2009, 9, 3275-3281.

135. Mangru, S.; Bentz, B.L.; Davis, T.J.; Desai, N.; Stabile, P.J.; Schmidt, J.J.; Millard, C.B.; Bavari, S.; Kodukula, K. Integrated bioassays in microfluidic devices: Botulinum toxin assays. $J$. Biomol. Screen 2005, 10, 788-794.

136. Moorthy, J.; Mensing, G.A.; Kim, D.; Mohanty, S.; Eddington, D.T.; Tepp, W.H.; Johnson, E.A.; Beebe, D.J. Microfluidic tectonics platform: A colorimetric, disposable botulinum toxin enzymelinked immunosorbent assay system. Electrophoresis 2004, 25, 1705-1713.

137. Ladd, J.; Taylor, A.D.; Homola, J.; Jiang, S.Y. Detection of botulinum neurotoxins in buffer and honey using a surface plasmon resonance (SPR) sensor. Sensor Actuat. B-Chem. 2008, 130, 129134.

138. Marconi, S.; Ferracci, G.; Berthomieu, M.; Kozaki, S.; Miquelis, R.; Boucraut, J.; Seagar, M.; Leveque, C. A protein chip membrane-capture assay for botulinum neurotoxin activity. Toxicol. Appl. Pharmacol. 2008, 233, 439-446.

139. Ferracci, G.; Miquelis, R.; Kozaki, S.; Seagar, M.; Leveque, C. Synaptic vesicle chips to assay botulinum neurotoxins. Biochem. J. 2005, 391, 659-666.

140. Wang, Y.L.; Chu, B.H.; Chen, K.H.; Chang, C.Y.; Lele, T.P.; Tseng, Y.; Pearton, S.J.; Ramage, J.; Hooten, D.; Dabiran, A.; Chow, P.P.; Ren, F. Botulinum toxin detection using AlGaN/GaN high electron mobility transistors. Appl. Phys. Lett. 2008, 93. 3-5.

141. Klaubert, B.; Vujtovic-Ockenga, N.; Wermter, R.; Schad, K.; von Meyer, L. Determination of botulinum toxins after peptic sample pre-treatment by multidimensional nanoscale liquid chromatography and nano-electrospray ion-trap mass spectrometry. J. Chromatogr. B. Analyt. Technol. Biomed. Life. Sci. 2009, 877, 1084-1092.

142. Wei, H.P.; Kang, Y.; Zhang, Z.P.; Cui, Z.Q.; Zhou, Y.F.; Zhang, X.E. Micellar electrokinetic chromatography and laser induced fluorescence detection of botulinum neurotoxin type A activity using a dual-labelled substrate. Int. J. Environ. Anal. Chem. 2008, 88, 947-956.

143. Liu, W.; Montana, V.; Chapman, E.R.; Mohideen, U.; Parpura, V. Botulinum toxin type B micromechanosensor. Proc. Natl. Acad. Sci. USA 2003, 100, 13621-13625.

144. Peruski, A.H.; Johnson, L.H. 3rd Ed.; Peruski, L.F. Rapid and sensitive detection of biological warfare agents using time-resolved fluorescence assays. J. Immunol. Methods. 2002, 263, 35-41.

145. Thyagarajan, B.; Krivitskaya, N.; Potian, J.G.; Hognason, K.; Garcia, C.C.; McArdle, J.J. Capsaicin protects mouse neuromuscular junctions from the neuroparalytic effects of botulinum neurotoxin a. J. Pharmacol. Exp. Ther. 2009, 331, 361-371.

146. Scarlatos, A.; Cadotte, A.J.; DeMarse, T.B.; Welt, B.A. Cortical networks grown on microelectrode arrays as a biosensor for botulinum toxin. J. Food Sci. 2008, 73, E129-136.

147. Boldt, G.E.; Eubanks, L.M.; Janda, K.D. Identification of a botulinum neurotoxin A protease inhibitor displaying efficacy in a cellular model. Chem. Commun. (Camb). 2006, 3063-3065.

(C) 2010 by the authors; licensee Molecular Diversity Preservation International, Basel, Switzerland. This article is an open-access article distributed under the terms and conditions of the Creative Commons Attribution license (http://creativecommons.org/licenses/by/3.0/). 